\title{
Significance of the Tambien Group (Tigrai, N. Ethiopia) for Snowball Earth events in the Arabian-Nubian Shield
}

\author{
Nathan R. Miller ${ }^{\mathrm{a}, *}$, Mulugeta Alene ${ }^{\mathrm{b}}$, Rosalino Sacchi ${ }^{\mathrm{c}}$, Robert J. Stern ${ }^{\mathrm{a}}$, \\ Anna Conti ${ }^{\mathrm{d}}$, Alfred Kröner ${ }^{\mathrm{e}}$, Gianmaria Zuppi ${ }^{\mathrm{f}}$ \\ a Geosciences Department, University of Texas at Dallas, Richardson, TX 75083-0688, USA \\ ${ }^{\mathrm{b}}$ Department of Geology and Geophysics, Addis Ababa University, PO Box 1176, Addis Ababa, Ethiopia \\ ${ }^{c}$ Dipartimento di Scienze Mineralogiche e Petrologiche, Università di Torino, 10125 Torino, Italy \\ ${ }^{\mathrm{d}}$ Laboratorio ISO4 clo DST, Università di Torino, 10125 Torino, Italy \\ e Institut für Geowissenschaften, Universität Mainz, 55099 Mainz, Germany \\ ${ }^{\mathrm{f}}$ Dipartimento di Scienze Ambientali, Università di Venezia, Venezia, Italy
}

Received 31 July 2002; accepted 12 January 2003

\begin{abstract}
Juvenile continental crust of the Arabian-Nubian Shield (ANS) formed within a Neoproterozoic supercontinent cycle. Subsequent late Neoproterozoic deposition overlapped a series of dramatic climatic events that are unparalleled in subsequent Phanerozoic time, as proposed by the "Snowball Earth" hypothesis. In particular, extreme negative $\delta^{13} \mathrm{C}$ excursions coincident with glacial diamictite and cap carbonate sequences imply that profound carbon flux changes accompanied widespread glacial transitions (Snowball Events). Such a succession appears to be partially preserved in metasediments of the diamictite-bearing Tambien Group of northern Ethiopia (Negash syncline). Here, a pronounced negative carbon excursion from values of +7 to -2 per mil accompanies the transition to diamictite deposition. New zircon evaporation dates from granites intruding the base of the sequence but post-dating early deformation of the entire sequence suggest that the Tambien Group is older than $613 \mathrm{Ma}$, and therefore diamictite genesis is incompatible with younger Marinoan, Varanger, or "Ediacaran" glacial intervals. Syn-tectonic granites elsewhere within the region date between 750 and $800 \mathrm{Ma}$ and provide an older age constraint for the Tambien Group. The limestone sequence underlying the diamictite has an average ${ }^{87} \mathrm{Sr} /{ }^{86} \mathrm{Sr}$ composition of 0.7066 , which supports either a middle (ca. 750-740 Ma) or late (ca. 725-720 Ma) Sturtian age. Combined $\mathrm{Sr}$ and $\mathrm{C}$ isotopic compositions of the limestones and the upper age constraint from the granite ages provide a compelling argument that the Tambien Group sediments are $\sim 720-750 \mathrm{Ma}$ or a little older and strongly support the prospect that the Negash diamictite is the product of Sturtian glaciation. If so, these are the first Sturtian Snowball Earth sequences identified in the ANS.
\end{abstract}

(C) 2003 Elsevier Science B.V. All rights reserved.

Keywords: Neoproterozoic; Ethiopia; Arabian-Nubian Shield; $\delta^{13} \mathrm{C} ;{ }^{87} \mathrm{Sr} /{ }^{86} \mathrm{Sr}$; Snowball Earth hypothesis

\section{Introduction}

The Neoproterozoic Era (900-544 Ma) was a time of unparalleled climatic events, most spectacularly re-

\footnotetext{
* Corresponding author. Fax: +1-972-883-2537.

E-mail address: miller@utdallas.edu (N.R. Miller).
}

flected in the "Snowball Earth" hypothesis (Hoffman and Schrag, 2002). This argues that large parts of the Earth's surface were covered by ice and glaciers at least twice, first about $700 \mathrm{Ma}$ (Sturtian glaciation) and again at about $600 \mathrm{Ma}$ (Marinoan, Varanger, or Vendian glaciation). Each of these glacial episodes is thought to have ended suddenly, resulting in a very 
warm climate. Evidence for these events-in the form of tillite deposits overlain by cap carbonates and associated extreme $\delta^{13} \mathrm{C}$ excursions-has been found all over the Earth (Fig. 1). Understanding the cause and effects of these episodes is a focus of international geoscientific research (e.g. Kirschvink, 1992; Hoffman et al., 1998a,b; for an exhaustive review, see Evans, 2000).

The Neoproterozoic also witnessed important tectonic events, most notably the breakup of the supercontinent Rodinia in the first half of the era and the formation of the new supercontinent, Gondwana, near the era's end (Stern, 1994). This Neoproterozoic supercontinent cycle was accompanied by the closure of a major ocean basin, known as the Mozambique Ocean (Stern, 1994). Subduction to close the Mozambique
Ocean generated numerous island arcs. These collided about 800-650 Ma ago to form the Arabian-Nubian Shield (ANS), which contains the bulk of global juvenile continental crust of Neoproterozoic age (Patchett and Chase, 2002). Accretion of island arcs and microcontinents and terminal collision between parts of $\mathrm{E}$ and W Gondwana at about $600 \mathrm{Ma}$ formed the East African Orogen (Kröner, 2001; Meert, 2003).

Given the abundance of Neoproterozoic crust in the region (Fig. 2A), it is surprising that successions similar to Snowball Earth sequences elsewhere have not been reported from the ANS. The lack of $\sim 600 \mathrm{Ma}$ glacial deposits may reflect the likelihood that the region was an elevated landmass in a polar position (Dalziel, 1997) by this time, so that the principal effects of the $\sim 600 \mathrm{Ma}$ glaciation may have been the

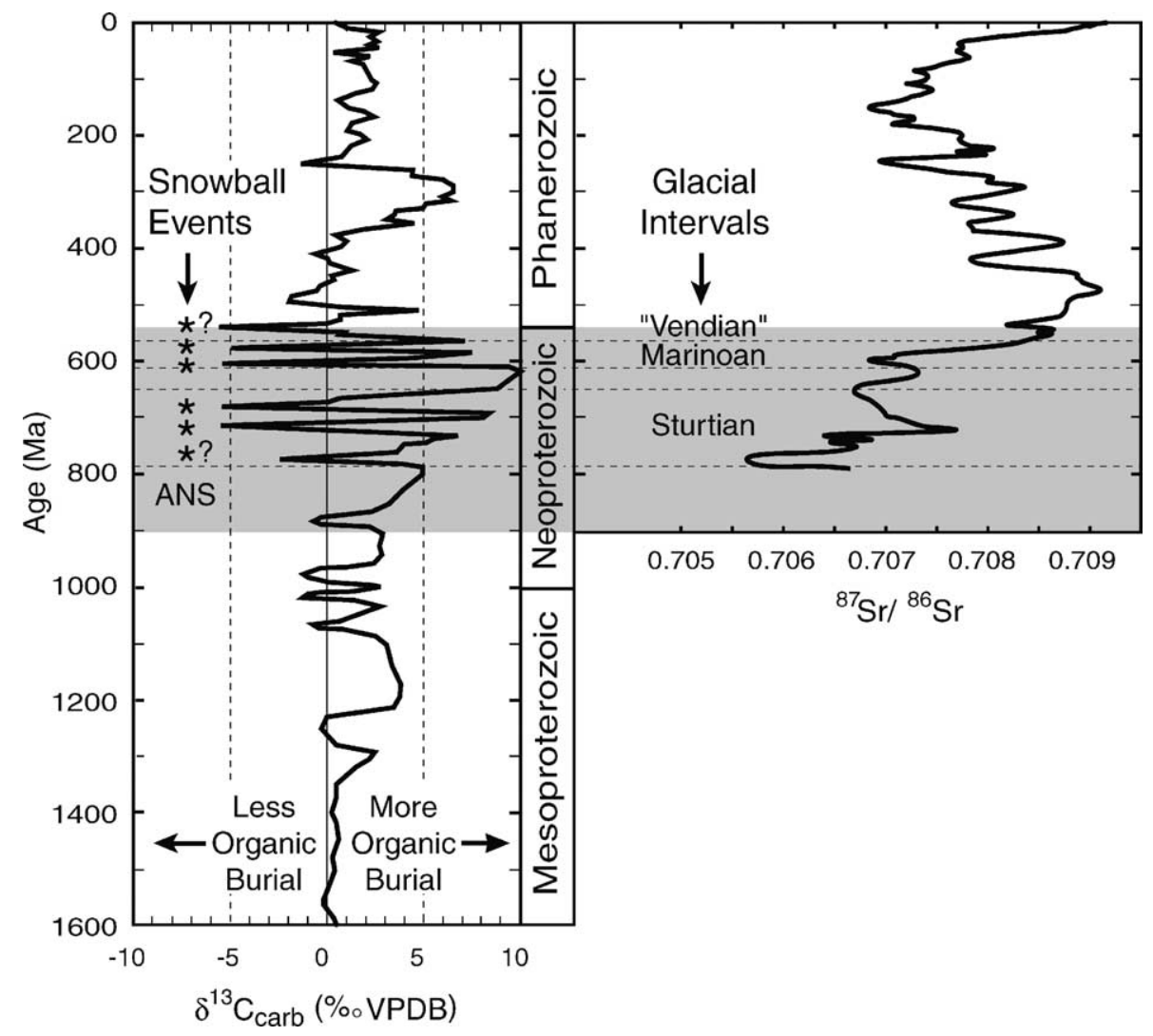

Fig. 1. Secular variation in the carbon isotopic composition of shallow marine carbonates over the last 1600 million years, showing the timing of ANS basement rocks (shaded field) relative to "Snowball" carbon isotope excursions. Excursions correspond to "Ediacaran" (ca. 570 Ma), Marinoan (M1 \& M2), and Sturtian (S1 \& S2) glaciations. Figure modified from Hoffman et al. (1998a). Neoproterozoic seawater strontium isotope variation (510-800 Ma) relative to timing of potential "Snowball Events" in the ANS. Modified from Jacobsen and Kaufman (1999). 

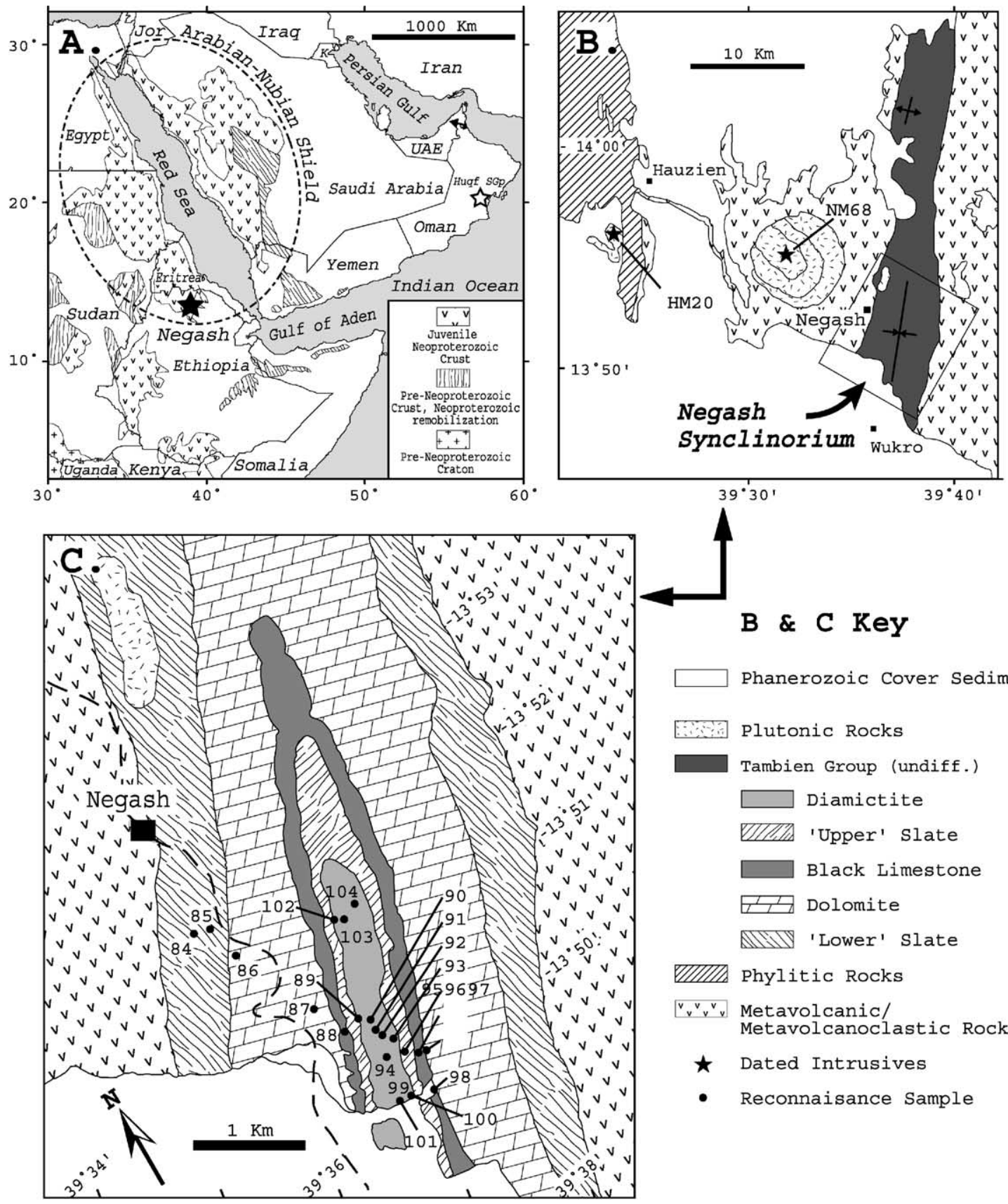

\section{B \& C Key}

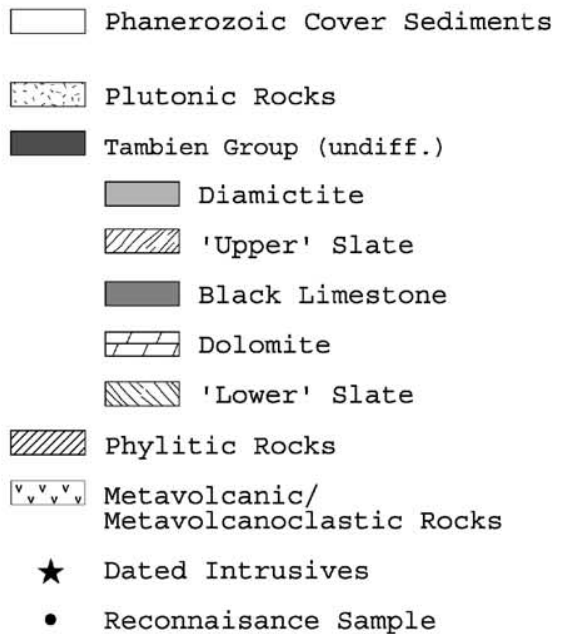

Fig. 2. (A) Location of Negash study area in northern Ethiopia within juvenile Neoproterozoic crust of the ANS and location of Huqf Supergroup sequences in Oman. (B) Generalized geologic map of Negash-Hauzien study area showing location of Negash syncline and Tambien Group metasediments relative to underlying Tsaliet Group metavolcanics/metavolcaniclastics, intrusive Mereb granite (plutonic rocks), and overlying Phanerozoic cover sediments. (C) Close-up view of Negash syncline showing differentiated Tambien Group units and corresponding sample localities. 
cutting of the end-Neoproterozoic peneplain. Additional complications come from widespread and pervasive deformation. Nevertheless, it is reasonable to expect that some record of the Sturtian glacial episode would be preserved in the ANS, especially because during this time much of the region that collapsed to form the ANS was at or below sea level.

One outcome of global research to understand Neoproterozoic climate is an improved database of $\mathrm{Sr}$ and $\mathrm{C}$ isotopic compositions for the era. Coupling of marine carbonate carbon and strontium isotope records now offers refined opportunities to correlate and date diamictite-bearing Neoproterozoic sequences. Here we present results of stable and $\mathrm{Sr}$ isotopic analyses performed on reconnaissance samples of the diamictite-bearing Tambien Group from the Negash area of northern Ethiopia (Tigrai region; Fig. 2). These data are integrated with new single zircon ${ }^{207} \mathrm{~Pb} /{ }^{206} \mathrm{~Pb}$ ages from granites intruding the base of the metasedimentary sequence, in order to evaluate the origin of the Negash diamictite relative to documented Neoproterozoic glaciogenic sequences. Our results indicate that metasedimentary rocks of the Tambien Group in northern Ethiopia preserve a record of Sturtian Snowball Earth events. More systematic investigation of the Tambien Group stratigraphy is proposed based on this reconnaissance study.

\section{Regional setting}

The Neoproterozoic basement of Ethiopia (Fig. 2) lies at the transition between the northern and southern sectors of the East African Orogen. It is compositionally similar to juvenile ANS crust but its structure is dominated by $\mathrm{N}-\mathrm{S}$ trending "shortening zones" (Abdelsalam and Stern, 1996) more common to the south. Beyth (1972) identified two major sequences in the basement of Tigrai, northern Ethiopia: an older predominantly metavolcanic sequence named the Tsaliet Group, and a younger metasedimentary succession named the Tambien Group. An intervening phyllite unit displays a transitional lithology that has been variously interpreted as metasedimentary (Arkin et al., 1971) and metavolcanic (Garland, 1972, 1980). Identification of several distinct terranes that make up the basement of Eritrea and northern Ethiopia (De Souza Filho and Drury, 1998; Tadesse et al., 1999) make regional correlations difficult, but a sequence in Eritrea similar to the Tsaliet Group yielded a zircon age of $854 \pm 3 \mathrm{Ma}$ (Teklay, 1997). Units similar to the Tsaliet Group to the west are intruded by syntectonic granodiorites, which yielded $\mathrm{Sm}-\mathrm{Nd}$ and $\mathrm{Rb}-\mathrm{Sr}$ isochron ages of 720-800 Ma (Tadesse et al., 2000). All basement units are unconformably overlain by undeformed Paleozoic cover.

The Tambien Group is exposed in three isolated synclinoria, from west to east: Shiraro, Mai Kenetal, and Negash (Beyth, 1972). Beyth (1972) described the contact of the Tambien Group with the underlying metavolcanics as "probably unconformable". The age of the Tambien Group is poorly constrained. Granitoid plutons, collectively known as "Mereb" Granite (Beyth, 1972), locally intrude the metavolcanics and lowermost metasediments. Within the Negash syncline, "pink granite" (believed to be a Mereb granite) intruded at least the lower part of the metasedimentary sequence.

In the Negash area, the section we studied and recently remapped by one of us (M. Alene) at a $1: 50,000$ scale, the sequence is over $2 \mathrm{~km}$ thick and is mainly composed of slates, graphitic slates, phyllites, greywackes, limestone and quartzitic dolomites. The Negash metasedimentary sequence is topped by a diamictite in the core of the Negash syncline. The diamictite occurs as a pebbly slate interval that overlies slate and locally stromatolitic limestone (Fig. 3). The upward transition into the lower diamictite involves limestone interbeds of varying thickness. Beyth (1972) interpreted this diamictite as a tillite, although compelling evidence such as dropstones is lacking.

The Tambien Group in the Negash syncline was subjected to two phases of folding. D1 and D2 are the result of $\mathrm{N}-\mathrm{S}$ and $\mathrm{E}-\mathrm{W}$ regional compression, respectively (Alene, 1998; Alene and Sacchi, 2000). D1 folded primary bedding and produced tight to isoclinal minor folds, elongation lineations and a pervasive regional foliation-including a transposed fabric. D2 caused large, predominantly upright, open folds with sub-horizontal axes without producing a pervasive cleavage. Structural evidence within their contact zones shows that many of the Mereb granitoids probably intruded the Tambien Group prior to D2. D2-structures are most simply explained as reflecting terminal collision between $\mathrm{E}$ and $\mathrm{W}$ Gondwana, and 

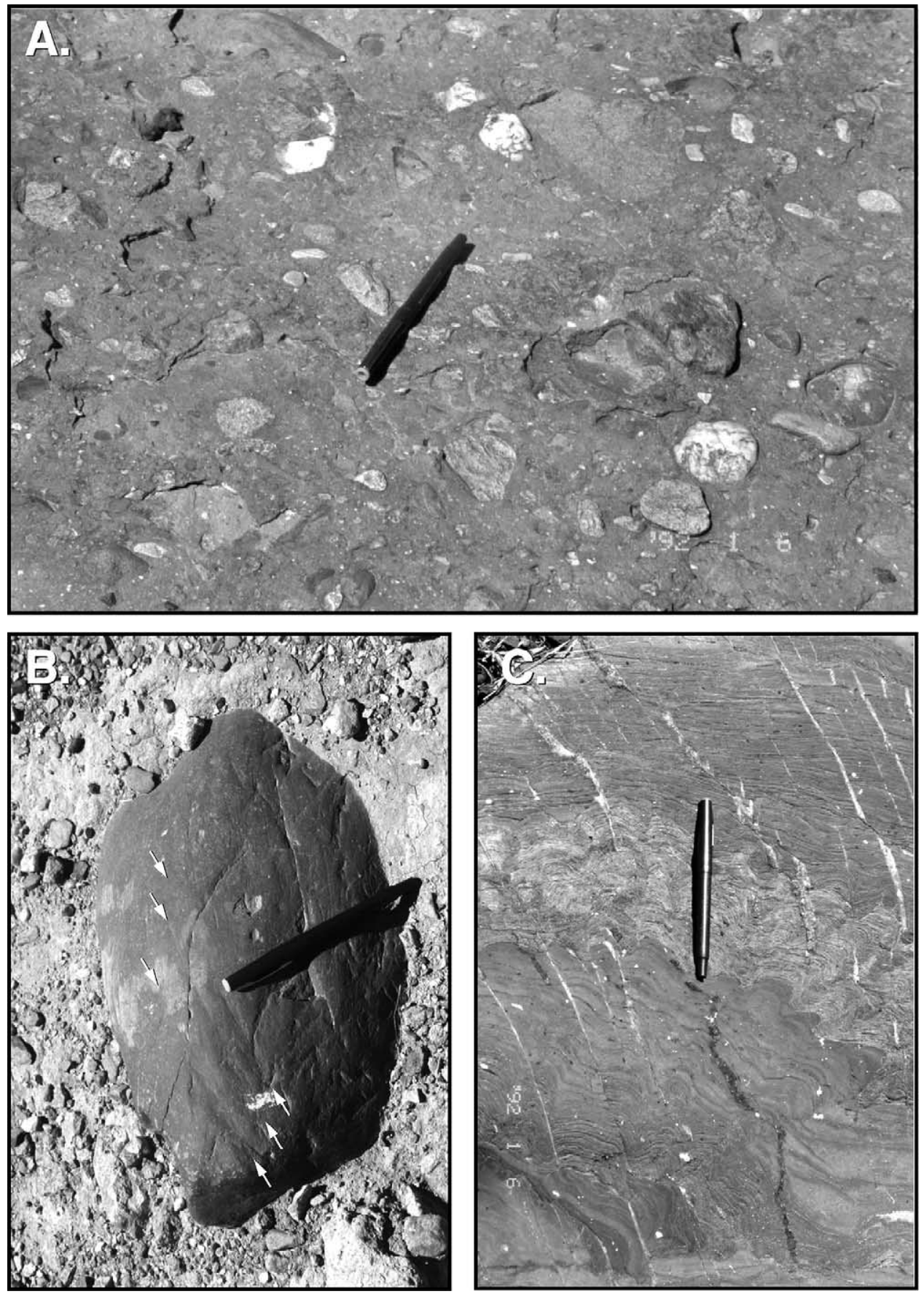

Fig. 3. Field photographs of Negash diamictite showing (A) rounded to sub-angular clasts of contrasting size and lithology and (B) polished cobble with parallel striations (arrows) of possible glaciogenic origin. (C) Field photograph of well-preserved stromatolitic limestone from the Black Limestone unit below the Pebbly Slate (diamictite). Laminated columnar heads, partially offset by a pervasive structure-induced fracture system, indicate the original upward growth direction is to the top. Late structure-induced fractures are filled by calcite and silica. Pen is $14 \mathrm{~cm}$ in length. 
this is consistent with the new zircon ages reported below. Mineral assemblages and textural features point to three metamorphic phases: (1) an early, regional pumpellyite-actinolite to lower-greenschist facies coeval with D1; (2) a local contact metamorphism (growth of andalusite and staurolite) caused by granitoid intrusion; and (3) a late phase probably related to D2 folding and uplift. Chlorite ${ }^{\mathrm{IV}} \mathrm{Al}$ geothermometry (Alene, 1998) suggests metamorphic temperatures in the range of $245-375^{\circ} \mathrm{C}$.

\subsection{The Tambien Group metasedimentary sequence}

The lithostratigraphy of the Tambien Group varies somewhat between the Negash and Mai Kenetal areas. Beyth (1972) and Arkin et al. (1971) considered respective stratigraphies within the Tambien Group. Garland (1972) subdivided the Negash sequence into Didikama and Matheos Formations and described them as units younger than, and different from, the Tambien Group. Here we consider the Negash sequence as part of the Tambien Group, but subdivide the lower and upper succession into Didikama and Matheos Formations, respectively.

The lowermost sub-unit (Didikama Formation sensu lato) of the metasedimentary sequence is well-displayed in the Negash area where it directly overlies the metavolcanic substrate (Fig. 2C). It consists of a basal slate (Lower Slate) and an overlying thick dolomite (Dolomite). Members of the uppermost sub-unit (Matheos Formation) include, from base to top, Massive Black Limestone (hereafter Black Limestone), Upper Slate, and Pebbly Slate (diamictite). These seem to be represented only in the Negash syncline, where they yielded the samples we analyzed. The Negash structure is an upright inclined synclinorium on older basement. The western limb is inverted, but the whole sedimentary sequence is not. Sedimentary geopetal structures, such as columnar stromatolitic lamination and channel-fill structures in the Black Limestone, indicate that the section youngs toward the diamictite. The lithologic transition from Black Limestone to Pebbly Slate (diamictite) consists of intercalated slate, black limestone and diamictite. Because slate is predominate in this interval it is considered, separately, as "Upper Slate". The contact between the Black Limestone and Upper Slate as well as that between the Upper Slate and Pebbly Slate (di- amictite) are thus "gradational" in the broad sense of intercalated lithologies. There is no significant lithologic or tectonic break in the sequence. Fig. 4 shows the composite stratigraphic column and the position of samples collected. The lithologic sequence that we sampled includes (from top to bottom):

- Pebbly Slate (diamictite): A well-foliated Pebbly Slate unit approximately $300 \mathrm{~m}$ thick. At several localities the slaty cleavage is crenulated, indicating that the rock has undergone at least two phases of ductile deformation. The rock contains abundant pebbles and cobbles of variable size (mostly 1-15 cm diameter), shape and composition. The pebbles are black limestone, mafic to felsic metavolcanic rocks, volcanic breccias, greywackes, quartzitic and granitic rocks. The matrix is composed of fine-grained quartz, mica, and very fine-grained dark aggregates. A thin $(\sim 7 \mathrm{~cm})$ Black Limestone layer is intercalated, low in the sequence (sample NW99). The basal contact is gradational over a zone of intercalated slate, Black Limestone, and diamictite. Although we use the nongenetic term "diamictite", the contrasting compositions of poorly sorted pebbles and cobbles are consistent with a glacial deposit. A localized mass flow deposit would likely host a more similar assemblage of clast lithologies. There are also polished surface cobbles with striations that could have originated during glacial transport (Fig. 3B).

- Upper Slate: Slate, pebbly slate and limestone interbedded over a thickness of $\sim 200 \mathrm{~m}$.

- Massive Black Limestone: A laminated, locally stromatolitic, limestone about $500 \mathrm{~m}$ thick, cut by fracture-fill quartz and calcite veins.

- Dolomite: A white to pinkish, fine- to coarse-grained dolomite unit about $1200 \mathrm{~m}$ thick, occurring as massive layers, often intercalated with slate and often displaying tight folding and re-folding.

- Lower Slate: A grey-green and purplish slate unit more than $150 \mathrm{~m}$ thick (Arkin et al., 1971), that displays foliation sub-parallel to layering.

\subsection{Mereb granites}

The Negash-Hauzien area (Fig. 2B) contains two major, felsic intrusive bodies (Beyth, 1972; Russo et al., 1997; Alene, 1998). These were geochemically 


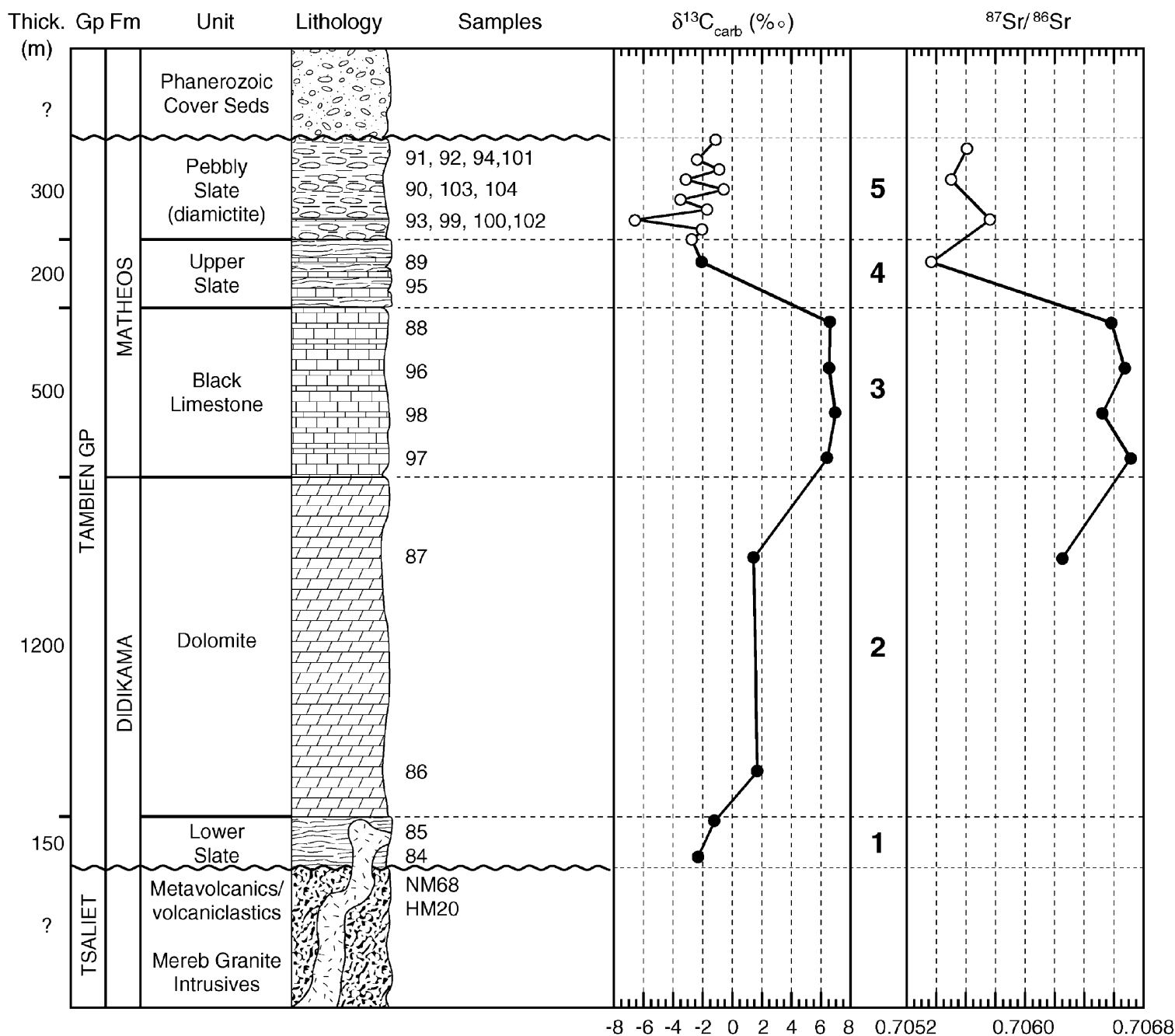

Fig. 4. Composite stratigraphic column for Negash syncline showing Tambien units, stratigraphic positions of reconnaissance samples, and corresponding carbon and strontium isotope compositions. Carbon isotope data from the Pebbly Slate (diamictite) interval are of uncertain preservation (see text) and denoted as open circles. Open circle samples in the ${ }^{87} \mathrm{Sr} /{ }^{86} \mathrm{Sr}$ plot are considered altered on the basis of geochemical criteria (see discussion). Stratigraphic order of units (1-5) as referenced in Fig. 8.

studied by Asfawossen (1997) and Alene et al. (2000). A few $\mathrm{km}$ west of the hinge of the N-S trending Negash syncline is the circular Negash Pluton (Asfawossen, 1997; and references therein), the largest $(8 \mathrm{~km}$ in diameter) intrusion in eastern Tigrai. Negash Pluton intrudes metavolcanics of the Tsaliet Group and has a roughly concentric inner structure. Its main lithology is granodiorite but it also contains a ring-shaped body of quartz diorite. Southwest of Hauzien, another ill-exposed anonymous granitic body (Hauzien Pluton hereafter) about $3 \mathrm{~km}$ in diameter intrudes the phyllite (Lower Slate) unit (although the contact is generally covered by scree). Both plutons show spaced foliation and other signs of deformation at outcrop scale. Each of these intrusions yielded a sample dated by the single-zircon $\mathrm{Pb} / \mathrm{Pb}$ evaporation method (Fig. 2B).

A third, yet unstudied, minor granitoid intrudes Lower Slate of the Negash syncline northeast of the town of Negash (Fig. 2C). The intrusion occurs as an 
elongate, N-NE-trending, body of pink granite about $2.5 \mathrm{~km}$ long and $0.9 \mathrm{~km}$ wide.

\section{Methodology}

Samples for stable isotope work were cleaned of external contaminants using a trim saw, then crushed in an agate mortar and pestle to obtain powder. Stable isotope $(\mathrm{C}$ and $\mathrm{O})$ compositions were determined on the bulk carbonate sample fraction by the classic method (McCrea, 1959) in which carbonate powder reacts in vacuum with $100 \%$ phosphoric acid at $25^{\circ} \mathrm{C}$. Isotope ratios were determined with a Finnigan MAT 250 mass spectrometer (Department of Earth Sciences, University of Turin) and are reported relative to the PDB standard. Analytical uncertainties are $\sim 0.10$ per mil for $\delta^{13} \mathrm{C}$ and $\delta^{18} \mathrm{O}$.

Following trim saw removal of external surfaces, strontium isotope samples were flash-etched in $1 \mathrm{~N}$ $\mathrm{HNO}_{3}$, thoroughly rinsed, dried, and crushed to powder. Major and minor cation contents were determined on weak ( $1 \mathrm{~N} \mathrm{HOAc})$ and strong $\left(3 \mathrm{~N} \mathrm{HNO}_{3}\right)$ acid soluble sample fractions. Aliquot solute concentrations were diluted to less than $1000 \mathrm{ppm}$, based on carbonate content, as estimated from the $3 \mathrm{~N} \mathrm{HNO}_{3}$ soluble fraction. Cation concentrations were determined on a Perkin-Elmer Optima 3300DV plasma emission spectrophotometer (Geosciences Department, University of Texas at Dallas) from linear portions of intensity versus concentration calibration curves established from measurement of calibration solutions.

Trace element criteria for assessing skeletal carbonate preservation and optimal strontium isotope sample have been proposed for the Phanerozoic (e.g. Denison et al., 1994; Baker et al., 1982; Veizer et al., 1983) and Precambrian (Brand and Veizer, 1980, 1981; Veizer et al., 1983; Derry et al., 1989, 1992; Asmerom et al., 1991; Kaufman et al., 1993). Loss of Sr and incorporation of $\mathrm{Fe}$ and/or $\mathrm{Mn}$ often indicate diagenesis of marine carbonates. While there is often a net loss of $\mathrm{Sr}$, addition of $\mathrm{Fe}$ and $\mathrm{Mn}$ support the prospect that the Sr pool may contain externally derived contaminant Sr. Accordingly, samples with low $\mathrm{Sr}$ contents and high $\mathrm{Fe} / \mathrm{Sr}$ or $\mathrm{Mn} / \mathrm{Sr}$ are least likely to preserve the original marine ${ }^{87} \mathrm{Sr} /{ }^{86} \mathrm{Sr}$.

To further minimize contamination by foreign $\mathrm{Sr}$ associated with non-carbonate phases, processing of whole-rock samples ideally targets weak acid dissolution of less than $100 \%$ of the carbonate phase (Bailey et al., 2000). Accordingly, samples were leached using a volume of $1 \mathrm{~N}$ acetic acid sufficient to dissolve $90 \%$ of the total sample carbonate. Leachate strontium was extracted using polypropylene chromatography columns loaded with strontium-specific resin (EIChromM Sr Resin SPS). Following preconditioning $\left(3 \mathrm{~N} \mathrm{HNO}_{3}\right)$, samples were loaded and non-reactive phases eluted in $1 \mathrm{~N} \mathrm{HNO}_{3}$. Resin-bound $\mathrm{Sr}$ was collected as the aqueous eluate. Dried $\mathrm{Sr}$ extracts were diluted in ultra pure water and $2 \mu \mathrm{g}$ aliquots loaded in a tantalum oxide-phosphoric acid slurry onto crimped rhenium filaments.

Strontium isotopic compositions were determined using a Finnigan MAT-261 variable collector thermal ionization mass spectrometer at the University of Texas at Dallas. Samples were run in duplicate or triplicate. Isotopic measurement for each sample typically involved 160 static multicollection cycles of all four Sr isotopes in addition to ${ }^{85} \mathrm{Rb}$, for monitoring ${ }^{87} \mathrm{Rb}$. Strontium isotope standard NIST SRM-987 was analyzed prior to and following sample runs. Mass discrimination during evaporation and ionization of $\mathrm{Sr}$ was corrected for by normalizing $\mathrm{Sr}$ isotopic ratios to ${ }^{86} \mathrm{Sr} /{ }^{88} \mathrm{Sr}=0.1194$ using a linear correction scheme. During measurement, the ${ }^{88} \mathrm{Sr}^{+}$ion beam was maintained at $3.5 \pm 0.5 \mathrm{~V}$ on a $10^{-11} \Omega$ resistor. Precision of results is estimated to be within $25 \mathrm{ppm}$ based on external precision of standards during the analysis period. Reported ${ }^{87} \mathrm{Sr} /{ }^{86} \mathrm{Sr}$ results are normalized to the long-term mean for NBS-987 of $0.710242 \pm 0.000012$. To provide direct comparison of results with any laboratory, sample $\mathrm{Sr}$ isotope ratios are also reported as the difference from modern seawater $\left(\Delta_{\mathrm{sw}}\right)$. The $\Delta_{\mathrm{sw}}$ value of a sample is calculated from the formula:

$$
\begin{aligned}
\Delta_{\mathrm{sw}}= & \left({ }^{87} \mathrm{Sr} /{ }^{86} \mathrm{Sr}\right. \text { unknown } \\
& \left.-{ }^{87} \mathrm{Sr} /{ }^{86} \mathrm{Sr} \text { modern seawater }\right) \times 10^{5} .
\end{aligned}
$$

A weighted mean of modern seawater ${ }^{87} \mathrm{Sr} /{ }^{86} \mathrm{Sr}=$ $0.709180 \pm 0.000011$ is inferred from 11 measurements of modern carbonate standard EN-1.

Two plutons of Mereb granite from west of the Negash syncline (Fig. 2B) were selected for zircon dating by the single-zircon $\mathrm{Pb} / \mathrm{Pb}$ evaporation method. Laboratory procedures as well as comparisons with conventional and ion-microprobe zircon dating are 
Table 1

Stable and strontium isotope compositions, acid solubilities, and cation concentrations of Negash sample carbonate fractions

\begin{tabular}{|c|c|c|c|c|c|c|c|c|c|c|c|c|c|c|c|c|}
\hline Sample & Unit (lithology) & Formation & $\delta^{13} \mathrm{C}^{\mathrm{a}}$ & $\delta^{18} \mathrm{O}^{\mathrm{a}}$ & ${ }^{87} \mathrm{Sr} /{ }^{86} \mathrm{Sr}$ & $\Delta_{\mathrm{sw}}$ & $\begin{array}{l}\text { WAS } \\
\text { (wt.\%) }\end{array}$ & $\begin{array}{l}\text { SAS }^{\mathrm{c}} \\
\text { (wt.\%) }\end{array}$ & $\begin{array}{l}\mathrm{Ca} \\
(\mathrm{wt} . \%)\end{array}$ & $\begin{array}{l}\mathrm{Mg} \\
\text { (wt.\%) }\end{array}$ & $\begin{array}{l}\text { Sr } \\
(\mathrm{ppm})\end{array}$ & $\begin{array}{l}\mathrm{Si} \\
(\mathrm{ppm})\end{array}$ & $\begin{array}{l}\text { Al } \\
(\mathrm{ppm})\end{array}$ & $\begin{array}{l}\mathrm{K} \\
(\mathrm{ppm})\end{array}$ & $\begin{array}{l}\mathrm{Fe} \\
(\mathrm{ppm})\end{array}$ & $\begin{array}{l}\mathrm{Mn} \\
(\mathrm{ppm})\end{array}$ \\
\hline NW91 & Upper Diamictite (Pebbly Slate) & Matheos & -1.09 & -7.08 & & & 11 & 16 & 29.27 & 7.42 & 946 & 760 & 680 & 120 & 14589 & 6645 \\
\hline NW92 & Upper Diamictite (Pebbly Slate) & Matheos & -1.75 & -8.09 & $0.705603 \pm 14^{\mathrm{d}}$ & -357.7 & 12 & 17 & 40.29 & 0.40 & 1869 & 896 & 1323 & 464 & 3473 & 3632 \\
\hline NW94 & Upper Diamictite (Pebbly Slate) & Matheos & -2.36 & -7.68 & & & 6 & 14 & 39.97 & 1.42 & 804 & 1283 & 1932 & 974 & 1883 & 3232 \\
\hline NW101 & Upper Diamictite (Pebbly Slate) & Matheos & -0.86 & -6.06 & & & 14 & 24 & 36.67 & 3.09 & 571 & 782 & 924 & 140 & 1761 & 2079 \\
\hline NW90 & Middle Diamictite (slate) & Matheos & -3.11 & -11.35 & $0.705499 \pm 12^{\mathrm{d}}$ & -368.1 & 10 & 14 & 36.78 & 1.58 & 2762 & 722 & 1073 & 405 & 4246 & 5082 \\
\hline NW103 & Middle Diamictite (Pebbly Slate) & Matheos & -0.54 & -6.39 & & & 16 & 18 & 40.86 & 0.74 & 367 & 509 & 701 & 250 & 953 & 1105 \\
\hline NW104 & Middle Diamictite (Pebbly Slate) & Matheos & -3.49 & -7.89 & & & 1 & 5 & 29.35 & 0.98 & 782 & 9240 & 12001 & 3748 & 7061 & 9792 \\
\hline NW93 & Lower Diamictite (Pebbly Slate) & Matheos & -1.68 & -4.03 & & & 16 & 22 & 35.15 & 4.39 & 623 & 956 & 1052 & 407 & 2943 & 3086 \\
\hline NW99 & Lower Diamictite (Black Limestone) & Matheos & -6.51 & -8.29 & $0.705764 \pm 13^{\mathrm{d}}$ & -341.6 & 46 & 54 & 21.96 & 11.58 & 896 & 113 & 137 & 60 & 30918 & 6139 \\
\hline NW100 & Lower Diamictite (Pebbly Slate) & Matheos & -1.95 & -7.64 & & & 1 & 8 & 10.42 & 1.06 & 704 & 12383 & 17214 & 6509 & 6102 & 8416 \\
\hline NW102 & Lower Diamictite (Pebbly Slate) & Matheos & -2.71 & -5.42 & & & 8 & 14 & 39.62 & 0.31 & 458 & 665 & 796 & 815 & 985 & 1812 \\
\hline $\begin{array}{l}\text { NW89 } \\
\text { NW95 }\end{array}$ & $\begin{array}{l}\text { Upper Slate (Black Limestone) } \\
\text { Upper Slate (slate) }\end{array}$ & $\begin{array}{l}\text { Matheos } \\
\text { Matheos }\end{array}$ & -2.05 & -8.38 & $0.705365 \pm 13^{\mathrm{d}}$ & -381.5 & $\begin{array}{r}65 \\
1\end{array}$ & $\begin{array}{r}76 \\
1\end{array}$ & $\begin{array}{l}25.25 \\
16.54\end{array}$ & $\begin{array}{r}10.84 \\
2.26\end{array}$ & $\begin{array}{r}475 \\
1153\end{array}$ & $\begin{array}{r}41 \\
16305\end{array}$ & $\begin{array}{r}38 \\
19492\end{array}$ & $\begin{array}{r}46 \\
10475\end{array}$ & $\begin{array}{r}13168 \\
4678\end{array}$ & $\begin{array}{r}1597 \\
10949\end{array}$ \\
\hline NW88 & Black Limestone/marble & Matheos & 6.59 & -5.14 & $0.706583 \pm 13$ & -259.7 & 97 & 97 & 42.19 & 0.18 & 2052 & 5 & 0 & 10 & 107 & 199 \\
\hline NW96 & Black Limestone/marble & Matheos & 6.55 & -5.56 & $0.706674 \pm 12$ & -250.6 & 92 & 92 & 47.19 & 0.25 & 3726 & 7 & 0 & 17 & 828 & 97 \\
\hline NW98 & Black Limestone/marble & Matheos & 6.98 & -5.48 & $0.706523 \pm 13$ & -265.7 & 97 & 97 & 43.28 & 0.14 & 2361 & 7 & 0 & 7 & 156 & 65 \\
\hline NW97 & Black Limestone/marble & Matheos & 6.42 & -4.81 & $0.706713 \pm 13$ & -246.7 & 97 & 97 & 42.46 & 0.17 & 2700 & 3 & 0 & 3 & 112 & 79 \\
\hline NW87 & Dolomite & Didikama & 1.46 & -0.63 & $0.706252 \pm 14$ & -292.8 & 51 & 82 & 21.69 & 13.15 & 518 & 23 & 6 & 32 & 488 & 137 \\
\hline NW86 & Dolomite & Didikama & 1.71 & -4.20 & & & 19 & 93 & 19.90 & 11.99 & 259 & 42 & 0 & 57 & 1972 & 250 \\
\hline NW85 & Lower Slate & Didikama & -1.19 & -9.96 & & & 1 & 1 & 27.86 & 1.16 & 747 & 5898 & 9965 & 8135 & 5593 & 2852 \\
\hline NW84 & Lower Slate & Didikama & -2.31 & -13.51 & & & 3 & 8 & 34.76 & 5.89 & 605 & 1791 & 3035 & 294 & 2783 & 8421 \\
\hline
\end{tabular}

${ }^{\text {a }}$ Stable isotope compositions in ppt relative to PDB standard.

b Weak acid (1 $\mathrm{N}$ acetic acid) solubility.

c Strong acid (3N nitric acid) solubility.

d Samples with probable altered ${ }^{87} \mathrm{Sr} /{ }^{86} \mathrm{Sr}$ compositions.

Cation carbonate concentrations are for the weak acid soluble sample fraction. 
detailed in Kröner et al. (1991) and Kröner and Hegner (1998). Isotopic measurements were carried out on a Finnigan-MAT 261 mass spectrometer at the Max-Planck-Institut für Chemie in Mainz. Calculated ages and uncertainties are based on the means of all ratios evaluated and their $2 \sigma$ mean errors. Mean ages and errors for several zircons from the same sample are presented as weighted means of the entire population. In the case of combined data sets, the $2 \sigma$ mean error may become very low, and whenever this error was less than the reproducibility of the internal standard (error in ${ }^{207} \mathrm{~Pb} /{ }^{206} \mathrm{~Pb}^{*}=0.000026$, see Kröner et al., 2001) we have used the latter value.

The evaporation technique provides only $\mathrm{Pb}$ isotopic ratios, and all ${ }^{207} \mathrm{~Pb} /{ }^{206} \mathrm{~Pb}$ ages determined by this method are necessarily minimum ages. However, many studies have demonstrated that there is a very strong likelihood that these data represent true zircon crystallization ages when: (1) the ${ }^{207} \mathrm{~Pb} /{ }^{206} \mathrm{~Pb}$ ratio does not change with increasing temperature of evaporation and/or (2) repeated analyses of grains from the same sample at high evaporation temperatures yield the same isotopic ratios within error. Comparative studies by evaporation, conventional $\mathrm{U}-\mathrm{Pb}$ dating, and ion-microprobe analysis have shown this to be correct (Kröner et al., 1991, 2001; Cocherie et al., 1992; Jaeckel et al., 1997; Karabinos, 1997).

Granite compositional analyses were conducted at the University of Cagliari (Sardinia, Italy), and full methods are described in Alene (1998). Major and minor elements were determined on pressed pellets using a PW1400 XRF spectrometer and natural, international standards for calibration. Data reduction followed the alpha-factor method of Franzini et al. (1972). Trace elements including REE were determined using a Perkin-Elmer Sciex Elan 5000 model ICP-MS on dissolved samples, diluted with $\mathrm{Rh}$ and $\mathrm{Re}$ as internal standards.

\section{Analytical results}

\subsection{Stable isotopes}

Stable isotope compositions are reported in Table 1. Negash oxygen isotope values range from -13.5 to $-0.6 \%$. Tigrai rocks are vastly altered in low greenschist conditions. Extreme light oxygen isotopic compositions (i.e. $<-10 \%$ ) imply thermal re-equilibration involving diagenetic fluids during regional metamorphism (Alene et al., 1999). Such highly depleted compositions are common for Precambrian metasediments.

Carbon isotope values show regular stratigraphic variations over a $13 \%$ range (Fig. 4). Stratigraphically, the trend increases from $-2.3 \%$ in the Lower Slate to maximum values between 6.4 and $7.0 \%$ in the Black Limestone. The trend then decreases abruptly to a single -6.5 per mil analysis in a thin Black Limestone bed within the lower diamictite. Within the overlying diamictite, values range from -3.5 to $-0.5 \%$.

Table 2

Zircon morphology and isotopic data from single grain evaporation samples from Tigrai, northern Ethiopia

\begin{tabular}{|c|c|c|c|c|c|c|}
\hline $\begin{array}{l}\text { Sample } \\
\text { number }\end{array}$ & $\begin{array}{l}\text { Zircon color and } \\
\text { morphology }\end{array}$ & $\begin{array}{l}\text { Grain } \\
\text { number }\end{array}$ & $\begin{array}{l}\text { Mass } \\
\text { scans }\end{array}$ & $\begin{array}{l}\text { Evaporation } \\
\text { temperature }\left({ }^{\circ} \mathrm{C}\right)\end{array}$ & $\begin{array}{l}\text { Mean }{ }^{207} \mathrm{~Pb} /{ }^{206} \mathrm{~Pb} \text { ratio } \\
\text { and } 2 \sigma \text { mean error }\end{array}$ & $\begin{array}{l}{ }^{207} \mathrm{~Pb} /{ }^{206} \mathrm{~Pb} \text { age and } \\
2 \sigma \text { mean error }{ }^{\mathrm{a}}\end{array}$ \\
\hline \multirow[t]{4}{*}{ HM20 } & \multirow{3}{*}{$\begin{array}{l}\text { Clear to pink, thin, } \\
\text { long-prismatic, } \\
\text { idiomorphic }\end{array}$} & 1 & 83 & 1598 & $0.060295 \pm 42$ & $614.2 \pm 1.5$ \\
\hline & & 2 & 85 & 1600 & $0.060273 \pm 43$ & $613.4 \pm 1.5$ \\
\hline & & 3 & 95 & 1598 & $0.060254 \pm 41$ & $612.7 \pm 1.5$ \\
\hline & Mean of three grains & $1-3$ & 263 & & $0.060273 \pm 24$ & $613.4 \pm 0.9^{\mathrm{b}}$ \\
\hline \multirow[t]{4}{*}{ NM68 } & \multirow{3}{*}{$\begin{array}{l}\text { Light red-brown, } \\
\text { long-prismatic, } \\
\text { idiomorphic }\end{array}$} & 1 & 93 & 1599 & $0.060072 \pm 47$ & $606.2 \pm 1.7$ \\
\hline & & 2 & 86 & 1600 & $0.060056 \pm 33$ & $605.6 \pm 1.2$ \\
\hline & & 3 & 96 & 1597 & $0.060069 \pm 37$ & $606.1 \pm 1.3$ \\
\hline & Mean of three grains & $1-3$ & 275 & & $0.060066 \pm 23$ & $606.0 \pm 0.9^{\mathrm{b}}$ \\
\hline
\end{tabular}

\footnotetext{
${ }^{\text {a }}$ Number of ${ }^{207} \mathrm{~Pb} /{ }^{206} \mathrm{~Pb}$ ratios evaluated for age assessment. Observed mean ratio corrected for non-radiogenic $\mathrm{Pb}$ where necessary. Errors based on uncertainties in counting statistics.

${ }^{b}$ Errors of combined mean ages are based on reproducibility of internal standard at $0.000026(2 \sigma)$.
} 


\subsection{Sr isotope sample screening}

Table 1 lists Tigrai sample solubilities in weak (WAS) and strong (SAS) acids and carbonate cation

Table 3

Major and trace element data for Mareb granite samples west of Negash syncline

\begin{tabular}{|c|c|c|c|}
\hline Sample & NW68 & HM20 & Mean \\
\hline Area & Negash & Hauzien & Mareb \\
\hline Rock & Granodiorite & Granite & Granite $^{\mathrm{a}}$ \\
\hline \multicolumn{4}{|l|}{ In wt. $\%$} \\
\hline $\mathrm{SiO}_{2}$ & 64.82 & 68.58 & 69.78 \\
\hline $\mathrm{TiO}_{2}$ & 0.62 & 0.47 & 0.47 \\
\hline $\mathrm{Al}_{2} \mathrm{O}_{3}$ & 16.03 & 15.97 & 15.39 \\
\hline $\mathrm{FeO}^{\mathrm{a}}$ & 3.71 & 2.37 & 2.54 \\
\hline $\mathrm{MnO}$ & 0.06 & 0.05 & 0.05 \\
\hline $\mathrm{MgO}$ & 2.99 & 1.37 & 1.08 \\
\hline $\mathrm{CaO}$ & 3.22 & 2.31 & 2.25 \\
\hline $\mathrm{Na}_{2} \mathrm{O}$ & 4.69 & 4.47 & 4.24 \\
\hline $\mathrm{K}_{2} \mathrm{O}$ & 3.59 & 4.22 & 4.05 \\
\hline $\mathrm{P}_{2} \mathrm{O}_{5}$ & 0.28 & 0.18 & 0.15 \\
\hline Total & 100.00 & 100.00 & 100.00 \\
\hline \multicolumn{4}{|l|}{ In ppm } \\
\hline $\mathrm{Sc}$ & 8.6 & 5.4 & \\
\hline $\mathrm{V}$ & 81.7 & 35.3 & 39.5 \\
\hline $\mathrm{Cr}$ & 70.4 & 13.6 & 12.0 \\
\hline Co & 28.6 & 25.6 & 10.2 \\
\hline $\mathrm{Ni}$ & 40.2 & 7.7 & 14.0 \\
\hline $\mathrm{Ga}$ & 30.4 & 25.2 & 20.0 \\
\hline $\mathrm{Rb}$ & 44.7 & 53.6 & 117.8 \\
\hline $\mathrm{Y}$ & 14.7 & 14.6 & 14.3 \\
\hline $\mathrm{Zr}$ & 24.2 & 37.7 & 171.8 \\
\hline $\mathrm{Nb}$ & 6.1 & 7.5 & 8.3 \\
\hline $\mathrm{Hf}$ & 0.8 & 1.3 & 5.9 \\
\hline Th & 3.0 & 5.0 & 12.4 \\
\hline $\mathrm{U}$ & 1.3 & 2.5 & 4.2 \\
\hline $\mathrm{La}$ & 19.8 & 21.6 & 27.9 \\
\hline $\mathrm{Ce}$ & 40.4 & 43.0 & 61.4 \\
\hline $\operatorname{Pr}$ & 5.0 & 5.2 & \\
\hline $\mathrm{Nd}$ & 18.8 & 18.9 & 30.1 \\
\hline $\mathrm{Sm}$ & 3.7 & 3.5 & 5.3 \\
\hline $\mathrm{Eu}$ & 1.4 & 1.1 & 1.0 \\
\hline $\mathrm{Gd}$ & 4.0 & 3.7 & \\
\hline $\mathrm{Tb}$ & 0.4 & 0.4 & 0.5 \\
\hline Dy & 1.8 & 1.8 & \\
\hline Ho & 0.4 & 0.3 & \\
\hline $\mathrm{Er}$ & 1.1 & 1.1 & \\
\hline $\mathrm{Tm}$ & 0.1 & 0.1 & \\
\hline $\mathrm{Yb}$ & 0.9 & 0.9 & 1.7 \\
\hline $\mathrm{Lu}$ & 0.1 & 0.2 & 0.2 \\
\hline
\end{tabular}

${ }^{a}$ Mean of six analyses (Tadesse-Alemu, 1998). All data renormalized to $100 \%$ anhydrous.
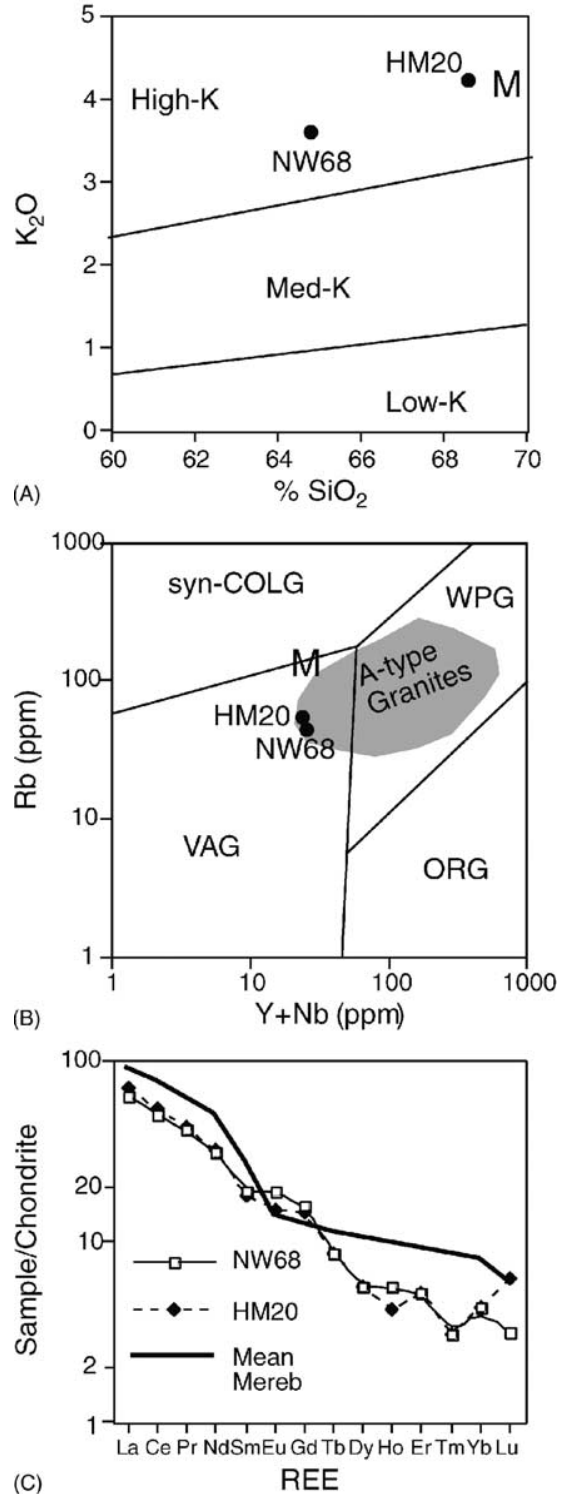

Fig. 5. (A) $\mathrm{K}_{2} \mathrm{O}-\mathrm{SiO}_{2}$ diagram, showing the high- $\mathrm{K}$ nature of Mereb-type granitic rocks (NW68, HM20) from the Negash syncline area. $\mathrm{M}$ : mean Mereb Granite. (B) $\mathrm{Rb}$ vs. $\mathrm{Y}+\mathrm{Nb}$ tectonic discriminant diagram. Fields (volcanic arc granite: VAG; ocean ridge granite: ORG; within-plate granite: WP; syn-collisional granite: syn-COLG) are from Pearce et al. (1984); A-type granite field from Whalen et al. (1987); M: mean Mereb Granite from Tadesse-Alemu (1998). (C) Chondrite-normalized REE diagram for Mereb-type granitic rocks from the Negash syncline area. Normalization after Boynton (1984). 
concentrations. Many samples proved to contain very little carbonate. Strong acid solubilities ranged between 1 and 97\%. Average solubilities were: Lower Slate $4.5 \%$, Dolomite $88 \%$, Black Limestone $96 \%$, Upper Slate $38.5 \%$, Pebbly Slate (limestone intercalation) $54 \%$, and Pebbly Slate $15 \%$. Samples richest in carbonate correspond to dolomites and black limestones underlying diamictite and overlying the Lower Slate units. If primary, carbonate fractions in these samples have the greatest chance of preserving marine ${ }^{87} \mathrm{Sr} /{ }^{86} \mathrm{Sr}$ compositions. Sr contents of Tambien Group samples range between 259 and $3726 \mathrm{ppm}$. Black Limestone (mean: $2710 \mathrm{ppm}$ ) and selected carbonate rich samples from the Upper Slate and Pebbly Slate (diamictite) were highest in $\mathrm{Sr}$. $\mathrm{Fe} / \mathrm{Sr}$ and $\mathrm{Mn} / \mathrm{Sr}$, respectively range from 0.04 to 34.5 and 0.03 to 13.9 . Nine samples meeting minimal sample preservation criteria $(\mathrm{Sr}>500 \mathrm{ppm}, \mathrm{Fe} / \mathrm{Sr}<2, \mathrm{Mn} / \mathrm{Sr}<2$, and strong acid solubility $>14 \%$ ) were ultimately selected for $\mathrm{Sr}$ isotope analysis. Rejected samples generally have elevated $\mathrm{Si}, \mathrm{Al}$, and $\mathrm{K}$ contents, further suggesting non-marine exchange. Not surprisingly, the most suitable samples within the Tigrai sequence were from Black Limestone and Dolomite units.

\section{3. ${ }^{87} \mathrm{Sr} /{ }^{86} \mathrm{Sr}$ results}

Strontium isotope compositions (Table 1, Fig. 4) range between 0.705405 and $0.706752\left(\Delta_{\mathrm{sw}}:-375.7\right.$ to -240.9$)$. Two populations of results are apparent; a "cluster" of values in the Black Limestone unit averaging $0.7066 \pm 0.0002\left(\Delta_{\mathrm{sw}}:-257.3 \pm 18.2\right)$ and a cluster of less radiogenic values averaging $0.7056 \pm 0.0002$ $\left(\Delta_{\text {sw }}:-356.4 \pm 16.9\right)$ in stratigraphically higher samples. The magnitude of variation $(0.001000)$ between these modal values is great, and there are no intermediate "continuum" samples.

\subsection{Chemical composition and single-zircon dating of Mereb granitoids}

Analytical data for the two Mereb granite plutons are presented in Table 2 and Fig. 6. NW68 is a sample of leucocratic, coarse-grained, unfoliated granodiorite from Negash Pluton, which intrudes metavolcaniclastic units. A feldspathized zone, abundant aplitic veins, and porphyroblastic texture mark the contact. The analyzed sample consists of $50 \%$ plagioclase, $10 \%$ perthitic K-feldspar, $20 \%$ quartz, $15 \%$ biotite,

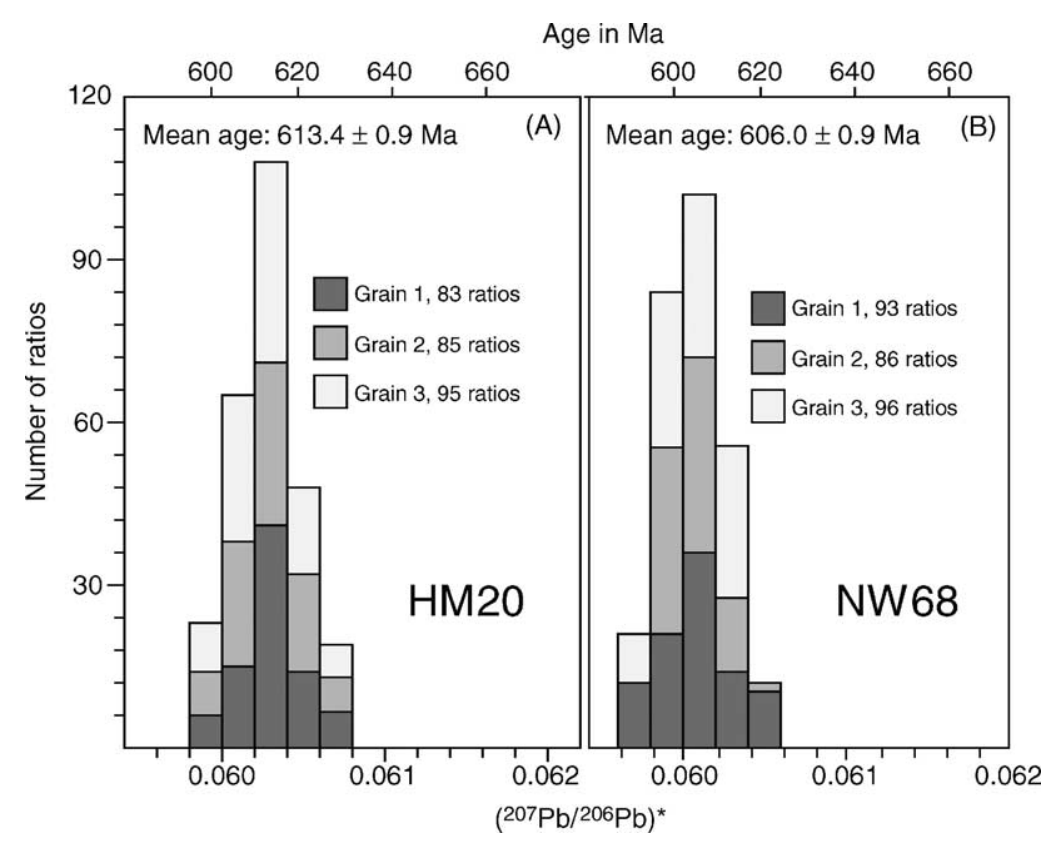

Fig. 6. Histograms showing distribution of radiogenic lead isotope ratios derived from evaporation of single zircons from Mereb-type granites. (A) Three zircon grains from Negash-Hauzien granite sample HM20, integrated from 263 ratios. (B) Three zircon grains from Negash-Hauzien granite sample NW68, integrated from 275 ratios. Mean ages are given with $2 \sigma$ (mean) error. 
and the remainder of amphibole and epidote, with accessory sphene and monazite. HM20 is a sample of a leucocratic, unfoliated, coarse-grained granite from Hauzien Pluton, which is clearly intrusive into the surrounding rock. It contains $40 \%$ quartz, $30 \%$ plagioclase, $25 \%$ perthitic K-feldspar, and 5\% biotite, along with minor epidote, calcite, and chlorite. Sphene or monazite is accessory.

Chemical analyses for the two samples are listed in Table 3 and shown in Fig. 5. Both plot in the field of high-K igneous rocks (Fig. 5A), as is typically observed for post-tectonic granites from the ANS (Pearce et al., 1984). In spite of field observations indicating that the granites are post-tectonic, they plot in the field of "volcanic arc granites", although along the margins of the field for "A-type" granites (Fig. 5B). The analyzed granitoids exhibit steep REE patterns, lack significant Eu anomalies, and are strongly depleted in HREE (Fig. 5C).

Three zircon grains were analyzed from each sample. Corresponding ${ }^{207} \mathrm{~Pb} /{ }^{206} \mathrm{~Pb}$ spectra are shown in Fig. 6 as histograms that permit visual assessment of the data distribution from which the ages are derived. The results for each cluster tightly and indicate that granodiorite NW68 has a mean ${ }^{207} \mathrm{~Pb} /{ }^{206} \mathrm{~Pb}$ age of $606 \pm 0.9 \mathrm{Ma}$, whereas granite HM20 is slightly older at $613.4 \pm 0.9 \mathrm{Ma}$.

\section{Discussion}

\subsection{Retention of primary isotopic ratios}

Documenting preservation of isotopic ratios is complicated in Precambrian rocks, particularly for metamorphosed sequences. Diagenetic exchange may degrade primary isotopic compositions of some systems, while leaving others intact. The range of measured $\delta^{18} \mathrm{O}$ in the samples that we have analyzed is consistent with the $\delta^{18} \mathrm{O}$ variation in Neoproterozoic (510-800 Ma) carbonate samples also considered to retain primary ${ }^{87} \mathrm{Sr} /{ }^{86} \mathrm{Sr}$ and $\delta^{13} \mathrm{C}$ (e.g. Fig. 6 in Jacobsen and Kaufman, 1999). However, because the Tambien Group sequence was affected by low-grade metamorphism, oxygen isotope stratigraphy was not further examined.

The carbon isotope record is likely to be more robust on the basis of theoretical grounds and empiri- cal comparison with other Neoproterozoic carbon isotope records. Although some of the analyzed samples contain very little carbonate (some $<10 \%$ ), carbon is comparatively buffered (conservative) compared to oxygen, which is exposed to much larger $\mathrm{O}$ reservoirs via hydrothermal and groundwater circulation. In contrast, carbonate units would be highly buffered in carbon and so relatively unaffected by carbon carried by such fluids. Furthermore, Tambien $\mathrm{C}$ isotope stratigraphic variations appear to be systematic on a first order basis and occur over a range that is consistent with other Neoproterozoic cap carbonate sequences considered to have preserved carbon isotope stratigraphies (Fig. 4, Fig. 8 later in the text). The nature of carbonate from the diamictite and the degree to which it records a primary marine composition are not readily discernable. Petrographic inspection indicates that calcite is largely dispersed in the clayey fraction of the sediment, with some oriented recrystallization. We cannot discount the possibility that the diamictite carbonate is altered, but its carbon isotope range appears to be consistent with a path of upward lightening $\delta^{13} \mathrm{C}$ beginning above the Black Limestone. Given this uncertainty, we denote diamictite $\delta^{13} \mathrm{C}$ values with open symbols in Fig. 4.

Strontium isotopes are likely to be best preserved in carbonate-rich lithologies that have not been extensively replaced or undergone diagenetic exchange. Trace elements coupled with acid solubility data demonstrate that the two populations of strontium isotope compositions derived from the Tambien Group correspond to carbonate with distinctly different chemical compositions. Compositions of the five most radiogenic samples are consistent with trace element criteria indicating preserved compositions (i.e. high carbonate content; low $\mathrm{Fe}, \mathrm{Mn}, \mathrm{Si}, \mathrm{Al}, \mathrm{K}$ relative to $\mathrm{Sr}$ ). Chemistries of the remaining samples that provided the least radiogenic ${ }^{87} \mathrm{Sr} /{ }^{86} \mathrm{Sr}$ compositions suggest more alteration. Fig. 7 plots these relations in relative stratigraphic order. Arrows indicate samples considered to retain primary marine $\mathrm{Sr}$ isotopic compositions Diagenetic incorporation of $\mathrm{Sr}$ derived from non-radiogenic igneous units is suggested for samples above the Black Limestone unit. Such an influence is not unreasonable considering the abundance of mafic igneous rock components within the diamictite and metavolcanic/metasedimentary Tsaliet basement. Although it is commonly thought that 

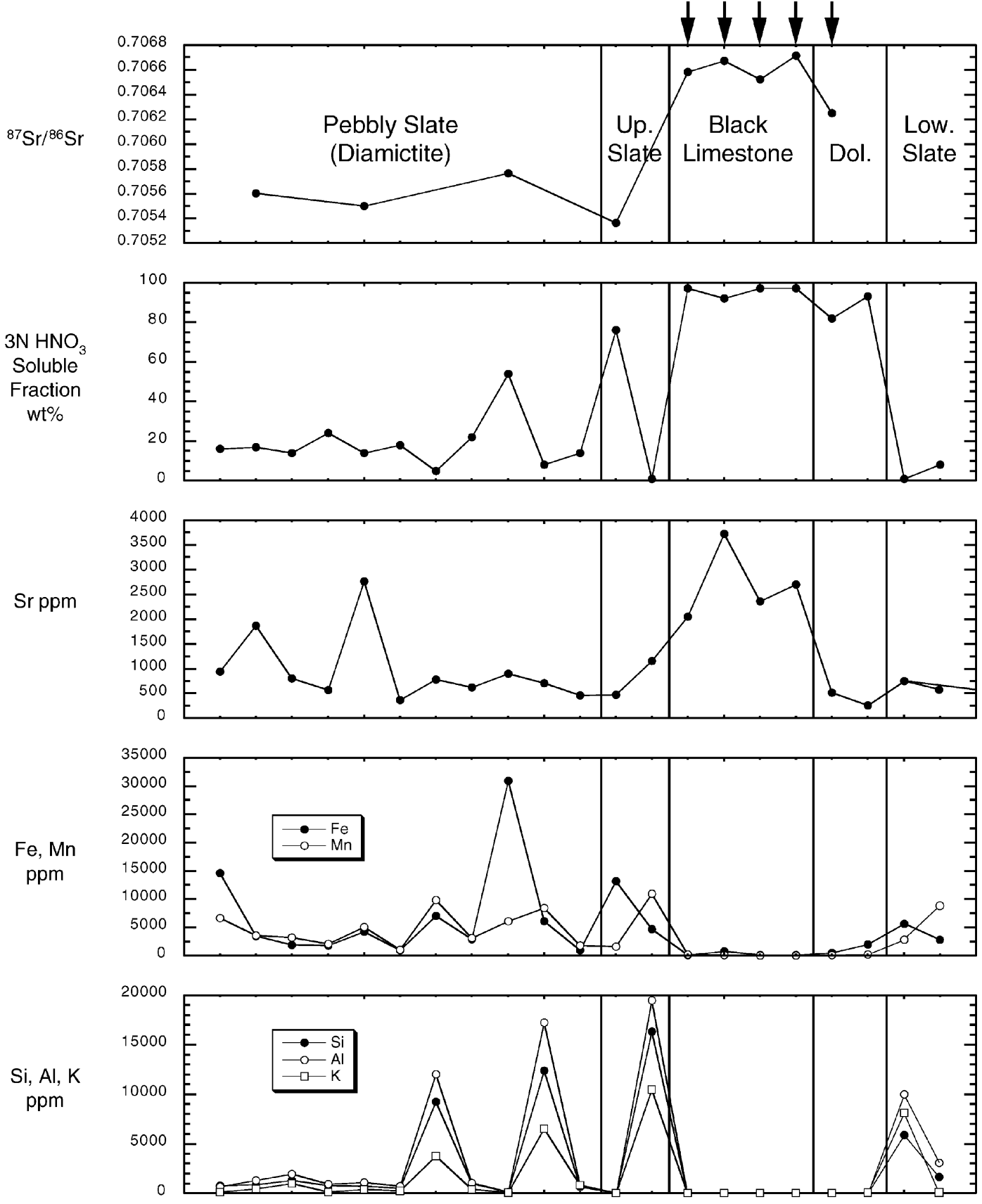

Stratigraphic Order

Fig. 7. Strontium isotope results for Negash samples and corresponding geochemical indices used to determine best-preserved samples. Optimal samples (arrows) have high carbonate (acid solubility) and $\mathrm{Sr}$ contents, and low concentrations of Fe, Mn, Si, Al, and K. Calcite and dolomite trace element concentrations are based on the weak acid soluble fraction from which Sr isotope compositions were derived. 
alteration results in anomalously high ${ }^{87} \mathrm{Sr} /{ }^{86} \mathrm{Sr}$ in the affected carbonate, this may not be the case in the ANS. Non-radiogenic Sr igneous rock compositions are typical of especially metavolcanic sequences like the Tsaliet elsewhere in the ANS (e.g. Stern and Abdelsalam, 1998), and remobilization of such non-radiogenic $\mathrm{Sr}$ and exchange with Tambien carbonates could be responsible for the unusual effect of more altered carbonates having less radiogenic $\mathrm{Sr}$ than carbonates that are better preserved.

\subsection{Age constraints for Tambien metasediments}

The granite intrusions offer important constraints on the age of the Tambien Group in the Negash area. Similar Mereb granites intrude at least the base of the Tambien Group and were emplaced after initial (D1) tectonic deformation of the entire sedimentary sequence. The Negash Pluton yielded a $\mathrm{Pb} / \mathrm{Pb}$ age of $606 \mathrm{Ma}$, and the Hauzien pluton gave an age of $613 \mathrm{Ma}$. We assume that the Negash syncline granite intrusion (undated) is also a Mereb granite and thus is coeval with the granites that we have dated. The Mereb granites in the study area are observed to intrude only the lower part of the Tambien Group. It is possible that there is a cryptic unconformity beneath the carbonates and diamictite, although evidence for this unconformity was not found. We interpret these ages and relationships as indicating that the Tambien Group in the Negash syncline is older than $613 \mathrm{Ma}$. This indicates that D1 deformation of the Tambien Group is older than $613 \mathrm{Ma}$. D2 deformation can be related to the development of $\mathrm{N}-\mathrm{S}$ trending upright folds and steep thrusts in the region, part of what Abdelsalam and Stern (1996) identified as shortening zones that formed in response to terminal collision between $\mathrm{E}$ and W Gondwana. If so, and if the dated granites were emplaced prior to D2, this constrains the terminal collision to have occurred after $613 \mathrm{Ma}$. This is consistent with other arguments for the age of this event (Meert, 2003). Although somewhat circular, this is another argument that the Tambien Group is older than $613 \mathrm{Ma}$.

The interpretation of the Tambien Group age relative to the dated intrusives is potentially complicated by the occurrence of granite pebbles within the Negash diamictite. The surrounding basement consists of intermediate metavolcanics and seems to contain no granite aside from the local Mereb intrusions. If the granite cobbles are of local origin, the age of the diamictite must be younger than $613 \mathrm{Ma}$ and the underlying sequence must contain an unconformity associated with the weathering and supply of Mereb granite to the diamictite. However, field evidence for this unconformity is not observed. Furthermore, the diamictite is deformed by D1 tectonism whereas the granite intrusives are not. If the diamictite is a tillite, far-traveled transport of granite from suitable source areas is plausible if not expected. Dearth of preserved Neoproterozoic sedimentary sequences in the region limits further evaluation of a glacial transport mechanism.

We tentatively interpret these ages and relationships to indicate that the Tambien Group in the Negash syncline is older than $613 \mathrm{Ma}$ and that the diamictite granite clasts are not clasts of the Mereb granite. A maximum age for the Tambien Group of 750-800 Ma is inferred from the age of syn-tectonic granites in the region that intrude the Tsaliet Group but not the Tambien Group (Tadesse et al., 2000). These age constraints are very important because they demonstrate that the Negash diamictite cannot have been deposited during the $\sim 600$ Ma glacial episode. If there really were only two major Neoproterozoic glacial intervals then deposition of the Tambien Group must be broadly Sturtian $(\sim 700 \mathrm{Ma})$. If so, carbon and strontium isotope data should be consistent with a Sturtian correlation.

\subsection{Carbon isotopic correlations}

The coarse $\delta^{13} \mathrm{C}$ stratigraphy afforded by our sample set (Fig. 4) appears to be a sufficient basis for correlation. Two significant points emerge from the Negash data. The first is the shift from positive values of the carbonate formation (Black Limestone $\delta^{13} \mathrm{C} \sim$ $+6 \%$ ) below the diamictite to negative values of the diamictite itself $\left(\delta^{13} \mathrm{C} \sim-2 \%\right.$ ) and especially that of its carbonate intercalation $\left({ }^{13} \mathrm{C} \sim-6 \%\right)$. Such variations, if primary, demonstrate profound changes in operation of the carbon cycle. Such trends are always present in association with Neoproterozoic tillites (i.e. Svalbard, East Greenland, Nordaustlandet-Knoll et al., 1986; Fairchild and Spiro, 1987; NW CanadaNarbonne et al., 1994; Kaufman et al., 1990; Asmerom et al., 1991; California-Prave, 1999; Congo Craton, Namibia-Kaufman et al., 1991; Oman (Brasier et al., 2000) and possibly Southern Norway-Tucker, 
1985 and Brazil-Iyer et al., 1995). Thus, the Black Limestone unit would appear to represent a Neoproterozoic pre-glacial $\delta^{13} \mathrm{C}$ positive excursion, which we have argued on other grounds must be broadly Sturtian in age.

The second point is the observed $>13 \%$ oxcursion (if the negative peak corresponding to the diamictite limestone intercalation is included), which greatly exceeds Phanerozoic values (Fig. 1). This intercalation, like cap carbonates in other settings, indicates a catastrophic decline in biological activity, or at least burial of organic $\mathrm{C}$. The diamictite, in fact, is at the top of the metasedimentary sequence and it is unknown whether it was ever capped by a cap carbonate. The shift to negative values took place before the diamictite was deposited, as has been described elsewhere (e.g. California; Prave, 1999). Similarity in the magnitude of the carbon excursion at other Neoproterozoic sections (e.g. Kaufman et al., 1997; Kah et al., 1999) suggests that Tigrai carbon compositions record a primary marine excursion.

The next question is which Sturtian interglacialglacial event is represented by the Negash facies? There is a growing consensus (Kennedy et al., 1998; Walter et al., 2000; Evans, 2000; Knoll, 2000) that at least two major glacial intervals (Sturtian at $>690-700 \mathrm{Ma}$ and a younger one at $\sim 600 \mathrm{Ma}$ ), corresponding to separate Snowball Events, took place during the Neoproterozoic; some workers postulate a third "Ediacaran" glacial event at ca. $570 \mathrm{Ma}$ (Kaufman and Knoll, 1995). Each of these apparently involved several discrete glacial events as documented by repetition of diamictites. The number of Neoproterozoic glaciations and at what time these occurred are subjects of ongoing debate (e.g. Kennedy et al., 1998; Melezhik et al., 2001) that our present dataset cannot resolve. We concern ourselves in this discussion only with a Sturtian event correlation. Delineating Neoproterozoic isotope stratigraphies is controversial. Considerable problems remain in establishing radiometric age correlations for demonstrably well-preserved sample sets among disparate global localities (see discussions in Melezhik et al., 2001 for a recent overview). We refer to the composite $\mathrm{C}$ and $\mathrm{Sr}$ isotope stratigraphies and age model compiled by Jacobsen and Kaufman (1999) for detailed consideration of Negash isotope correlations, recognizing that age models are subject to revision. Significantly, this study considered only samples with demonstrable preservation of both $\mathrm{C}$ and $\mathrm{Sr}$ isotopes and with radiometric age constraints. Their compilation indicates that there are two Sturtian $\delta^{13} \mathrm{C}$ excursions with magnitudes comparable to the Negash record (Fig. 8A). These excursions denote late (S1) and middle (S2) Sturtian events. A third, postulated, early Sturtian excursion (S3) appears to be of lower magnitude.

Local and integrated regional carbon isotope stratigraphies (e.g. Knoll et al., 1986; Jacobsen and Kaufman, 1999; Walter et al., 2000; Melezhik et al., 2001 ) indicate that the earliest $\sim 600$ Ma glacial event is separated from the latest Sturtian glacial interval by a pronounced interglacial period (" $\delta{ }^{13} \mathrm{C}$ plateau"; e.g. Fig. 8A), a period of perhaps 120 million years characterized by strongly positive $\delta^{13} \mathrm{C}$ values (in the range of +5 to $+10 \%$ ). This must correspond to a time without a biotic crisis characteristic of the two Snowball Earth episodes. Given the age constraints provided by the intrusive granites, the positive $\delta^{13} \mathrm{C}$ values of the Negash Black Limestone underlying the Pebbly Slate (diamictite) must predate this plateau. Potential matches are possible with either the S1 or S2 $\delta{ }^{13} \mathrm{C}$ excursions. Although absolute magnitudes of carbon isotope excursions show considerable variation, the Negash record is most similar to the range for the $\mathrm{S} 1$ event. Fig. 8A demonstrates potential correlations with these $\delta^{13} \mathrm{C}$-depletion events. The Negash carbon isotope stratigraphy overall documents an extensive basal stratigraphic interval $(\sim 1800 \mathrm{~m})$ of increasing $\delta^{13} \mathrm{C}$ culminating with the peak $(\sim 6.5 \%)$ in the Black Limestone and followed by a rapid decline to negative values in the Upper Slate and perhaps the Pebbly Slate (diamictite) $(\sim 500 \mathrm{~m}$; minimum: $-6.5 \%$, average: $-2.3 \%$ ). The overall stratigraphic rise and fall could constitute one discrete cycle (e.g. $\mathrm{S} 2$ or S1), or could span multiple cycles.

The lithostratigraphic distribution of $\delta^{13} \mathrm{C}$ values offers some further insight into these possibilities. The Black Limestone values offer potential matches with either S1 or S2 pre-glacial positives. If the Negash sequence represents only a single glacial event, then only the S1 rise accommodates measured values for the underlying Lower Slate and Dolomite $\left(\delta^{13} \mathrm{C}\right.$ Scenario 1). The Jacobsen and Kaufman (1999) age model suggests a period of about 20 million years for this scenario, which gives a composite overall accumulation rate (uncompacted; including the diamictite) of 

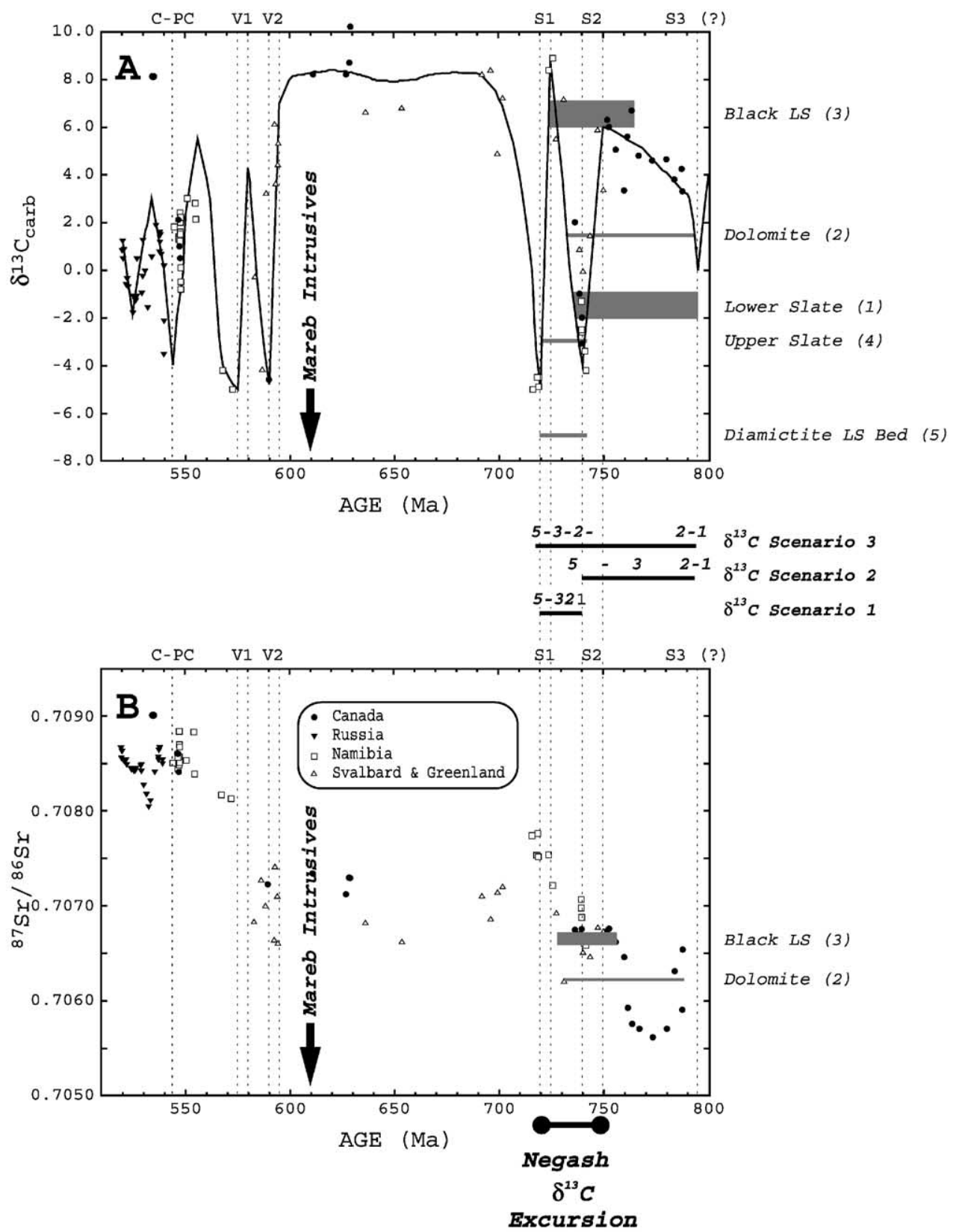

Fig. 8. Comparison of Negash facies isotope results with the composite carbon (A) and strontium (B) isotope stratigraphy of Jacobsen and Kaufman (1999). Jacobsen and Kaufman compilation (individual data points, curve fits, glacial intervals) based on samples judged to be well-preserved on the basis of geochemical criteria, having both $\delta^{13} \mathrm{C}$ and ${ }^{87} \mathrm{Sr} /{ }^{86} \mathrm{Sr}$ measurements, and having robust radiometric age constraints. Symbols in both plots denote localities according to the legend in plot B. Dashed vertical lines show estimated timing of glacial intervals: C-PC, Vendian; V1 and V2, upper and lower Marinoan/Varanger (undifferentiated); S1-S3, upper, middle, and lower Sturtian. Tambien isotopic correlation scenarios are constrained by Mereb granite intrusive dates (heavy arrows) to be older than $613 \mathrm{Ma}$. Negash facies isotope data are superimposed as shaded fields in each plot. Vertical and horizontal extents of each field respectively designate the range of isotopic variation measured for respective Tambien units and possible temporal correlations. Tambien units corresponding to each field are listed to the right; numbers designate base-to-top stratigraphic order (Fig. 4). Three possible $\delta^{13} \mathrm{C}$ correlation scenarios (see discussion) are shown between the plots. Negash $\mathrm{Sr}$ isotope data from the Black Limestone are consistent with a Sturtian carbon isotope excursion. 
about $118 \mathrm{~m}$ per million years $(0.12 \mathrm{~mm}$ per year $)$. Alternatively, the Negash sequence may correspond solely to the $\mathrm{S} 2$ cycle. This scenario $\left(\delta^{13} \mathrm{C}\right.$ Scenario 2) apparently requires deposition of thick dolomite within a short period, greater isotopic variations within the Dolomite unit than are currently resolved, or a hiatus to explain the lack of intermediate $\delta^{13} \mathrm{C}$ values between the uppermost Dolomite sample and the Black Limestone samples. The estimated duration for this scenario is 55 million years with an overall accumulation rate of $43 \mathrm{~m}$ per million years $(0.04 \mathrm{~mm}$ per year). A third correlation possibility suggested by the extreme stratigraphic thickness of the Dolomite interval $(\sim 1200 \mathrm{~m})$ and the nearly identical $\delta^{13} \mathrm{C}$ values measured near its base and top (Fig. 5) is that the Upper Slate and lowest Dolomite samples could represent deposition close in time to the position of the S3 low. The uppermost Dolomite sample would then correspond to the valley between $\mathrm{S} 2$ and $\mathrm{S} 1$ positives, with the Black Limestone positioned at the $\mathrm{S} 1$ peak $\left(\delta^{13} \mathrm{C}\right.$ Scenario 3). Estimated duration and composite accumulation rates for this scenario are 75 million years and $31 \mathrm{~m}$ per million years $(0.03 \mathrm{~mm}$ per year). The latter scenario, albeit speculative, offers the intriguing possibility that the Negash sequence may contain a record of earlier Snowball Earth climatic variation. Proposed higher resolution sampling of the Tambien Group for $\mathrm{C}$ and $\mathrm{Sr}$ isotope analysis should clarify the best $\delta^{13} \mathrm{C}$ correlation scenario for the Negash sequence.

\subsection{Relation to Neoproterozoic seawater ${ }^{87} \mathrm{Sr} /{ }^{86} \mathrm{Sr}$}

Fig. 8B shows the composite ${ }^{87} \mathrm{Sr} /{ }^{86} \mathrm{Sr}$ seawater dataset of Jacobsen and Kaufman (1999) and corresponding intersections indicated by the Negash samples. Strontium isotope compositions for the Black Limestone and underlying Dolomite are consistent with the Sturtian temporal scenarios postulated from carbon isotope constraints. This correspondence further suggests that the Negash samples are well preserved. Even though rejected samples (Fig. 4) from the Upper Slate and diamictite meet minimal sample preservation criteria, their ${ }^{87} \mathrm{Sr} /{ }^{86} \mathrm{Sr}$ compositions (0.7054-0.7058) could only correspond to the lowermost "valley" (ca. 785-760 Ma) corresponding to the Canadian Shaler Group. No comparable negative carbon excursion or diamictite is known within this interval. The path of Sturtian seawater ${ }^{87} \mathrm{Sr} /{ }^{86} \mathrm{Sr}$ evolution during the $\mathrm{S} 2$ and $\mathrm{S} 1$ carbon isotope excursions lacks clear delineation and involves compositing of data sets from Canada, Namibia, and Svalbard and Greenland. A single low value in the Svalbard and Greenland data set enables correlation of the Negash sequence according to $\delta^{13} \mathrm{C}$ Scenario 1 . Without this point, $\delta^{13} \mathrm{C}$ Scenarios 2 or 3 correlations are indicated. Given the apparent high rates of ${ }^{87} \mathrm{Sr} /{ }^{86} \mathrm{Sr}$ variation preceding S2 and possibly S1 (Fig. 8B), systematic strontium isotope stratigraphy of the Negash sequence would likely further constrain the correlation.

It should be mentioned that the Jacobsen and Kaufman (1999) strontium isotope curve involves some considerable changes to original age models of composite data sets. This curve differs substantially from that of Kuznetsov (1998), which is significantly less radiogenic (Melezhik et al., 2001; their Fig. 2). The Negash data would not intercept the Kuznetsov (1998) curve.

\subsection{Affinities with other Neoproterozoic glaciogenic sequences}

The correspondence of Negash data with S1 and/or $\mathrm{S} 2$ carbon isotope events suggests a genetic relationship with recognized sequences where these events were defined. A Sturtian negative carbon isotope excursion is recognized above the Shaler Group of Arctic Canada (Kaufman and Knoll, 1995) and lowermost Akademikerbreen Group in Svalbard (Derry et al., 1992), but glacial diamictites have not been recognized in either region. Sturtian diamictites do occur in the Mackenzie Mountains of Canada and Namibia (Kaufman and Knoll, 1995; Kaufman et al., 1997). Each of these localities also bears cap carbonates with negative $\delta^{13} \mathrm{C}$ and ${ }^{87} \mathrm{Sr} /{ }^{86} \mathrm{Sr}$ compositions that Jacobsen and Kaufman (1999) correlated with the former non-diamictite-bearing sequences as the middle Sturtian (S2) event (ca. $740 \mathrm{Ma}$ ). Evidence for the late Sturtian (S1) excursion comes from the Namibian Otavi succession, which contains two tillites: lower diamictites of the Chuos Formation, and 400 meters higher in the section diamictite of the Ghaub Formation. Both tillites are bounded by ${ }^{13} \mathrm{C}$-depleted carbonates above and ${ }^{13} \mathrm{C}$-enriched carbonates below. The age of the Otavi successions is disputed (Hoffman et al., 1998a,b; Kennedy et al., 1998). 
Other Sturtian excursions have been recognized in California and Oman. The Kingston Peak Formation of Death Valley, California, also bears a negative $\delta^{13} \mathrm{C}$ excursion in cap carbonate (Sourdough Limestone) overlying glacial diamictites considered to be Sturtian in age (Prave, 1999). The Ghubrah diamictite and overlying cap carbonate of the basal Huqf Supergroup in the Oman Mountains, Oman, coincide with a negative $\delta^{13} \mathrm{C}$ excursion (Burns and Matter, 1993). A U-Pb zircon tuff age of $723 \mathrm{Ma}$ from this diamictite suggests a Sturtian age (Brasier et al., 2000). The Ghubrah diamictite in Oman is currently the closest documented glaciogenic sequence to Negash (Fig. 2A). Perhaps the Huqf and Tambien Groups are correlative, but testing this speculation will require more work.

\section{Conclusions}

Our isotopic data, particularly the strong $\delta^{13} \mathrm{C}$ excursion across the diamictite and underlying sequence, lend support to Beyth's field diagnosis of the Negash diamictite as a tillite. The magnitude of the Negash carbon isotope excursion (+6.5 to $-6.5 \%$ ), its similarity to magnitudes of documented Neoproterozoic $\delta^{13} \mathrm{C}$ excursions, and its position directly beneath the Pebbly Slate (diamictite) are consistent with a greenhouse to icehouse transition. If the Negash diamictite is truly glaciogenic, the underlying depletion trend is consistent with the observation from classical "Snowball" sequences (Namibia) that carbonate rocks just before glacial deposits have $\delta^{13} \mathrm{C}$ that drops rapidly to volcanic equivalent levels $(\sim-6 \%$ ) (Hoffman et al., 1998b). In many glaciogenic sequences, the drop persists through "cap" carbonates on top of glacial deposits, and then slowly rebounds higher in the section.

Based on a comparison of carbon isotope records for the Neoproterozoic (Fig. 8A), several glacial intervals were preceded by seawater values close to $+6 \%$. The obvious potential glaciations are Sturtian (middle (S2) 750-740 Ma; late (S1) 725-720 Ma) and Marinoan (Varanger) (lower (V2) 595-590 Ma). Ages of granite intrusions indicate that the Tambien metasedimentary sequence in the Negash syncline must be older than $613 \mathrm{Ma}$, and thus could not include deposits associated with the younger $\sim 600 \mathrm{Ma}$ glaciations. A maximum age of $750-800 \mathrm{Ma}$ for the Tambien Group can be inferred from dating of syn-tectonic granites within the ANS. The composite Neoproterozoic seawater ${ }^{87} \mathrm{Sr} /{ }^{86} \mathrm{Sr}$ reference curve presented in Jacobsen and Kaufman (1999) enables multiple correlation possibilities for the Negash Black Limestone and Dolomite samples, but all support a Sturtian timeframe. Taken together, the combined $\mathrm{Sr}$ and $\mathrm{C}$ isotopic composition of the limestones and the age constraints from Mereb and ANS syntectonic granites provide a compelling argument that the Tambien Group sediments are $\sim 720-750 \mathrm{Ma}$ or a bit older and support the prospect that the Negash diamictite is the product of Sturtian glaciation. If so, these are the first Sturtian diamictites identified in the ANS.

The possibility remains that the Negash sequence may contain additional insights into the Sturtian Snowball Earth because the Black Limestone and Dolomite interval is only sparsely sampled. The estimated composite thickness of $1700 \mathrm{~m}$ indicates that a considerable time interval is represented. Moreover, Pebbly Slate intervals (diamictite candidates?) are recognized within the Dolomite unit. Biogeochemical data and high-resolution carbon (TOC and IC) and strontium isotope data should increase time resolution and may reveal additional details of Snowball Events within the ANS.

\section{Acknowledgements}

We thank Mohamed Abdelsalem for photographs of Negash diamictite and limestone facies. We also appreciate thoughtful reviews by J. Karhu and M. Brasier. This is UTD Geosciences Contribution 991.

\section{References}

Abdelsalam, M.G., Stern, R.J., 1996. Sutures and shear zones in the Arabian-Nubian Shield. J. Afr. Earth Sci. 23, 289-310.

Alene, M., 1998. Tectonomagmatic evolution of the Neoproterozoic rocks of the Mai Kenetal-Negash area, Tigrai, northern Ethiopia. Unpublished Ph.D. thesis, University of Turin, Italy.

Alene, M., Sacchi, R., 2000. The Neoproterozoic low-grade basement of Tigrai, northern Ethiopia. J. Afr. Earth Sci. 30, 5-6.

Alene, M., Conti, A., Sacchi, R., Zuppi, G., 1999. Stable isotope composition $\left({ }^{13} \mathrm{C}\right.$ and $\left.{ }^{18} \mathrm{O}\right)$ of Neoproterozoic limestones and dolomites from Tigrai, North Ethiopia. Boll. Soc. Geol. Italy $118,611-615$. 
Alene, M., Ruffini, R., Sacchi, R., 2000. Geochemistry and geotectonic setting of Neoproterozoic rocks from northern Ethiopia (Arabian-Nubian Shield). Gondwana Res. 3, 333-347.

Arkin, Y., Beyth, M., Dow, D.B., Levitte, B., Temesgen, H., Tsegaye H., 1971. The Geological map of Mekele area (1:250,000). Ministry of Mines, Addis Ababa.

Asfawossen, A., 1997. Geology and geochemistry of the Negash Pluton and their metallogenic significance, central Tigrai. Unpublished M.Sc. thesis, Addis Ababa University, Ethiopia.

Asmerom, Y., Jacobsen, S.B., Knoll, A.H., Butterfield, N.J., Swett, K., 1991. Strontium isotope variations of Neoproterozoic seawater: implications for crustal evolution. Geochim. Cosmochim. Acta 55, 2883-2894.

Bailey, T.R., McArthur, J.M., Prince, H., Thirlwall, M.F., 2000. Dissolution methods for strontium isotope stratigraphy: whole rock analysis. Chem. Geol. 167, 313-319.

Baker, P.A., Gieskes, J.M., Elderfield, H., 1982. Diagenesis of carbonates in deep-sea sediments. Evidence from $\mathrm{Ca} / \mathrm{Sr}$ ratios and interstitial dissolved $\mathrm{Sr}^{2+}$ data. J. Sediment. Petrol. 52, 71-82.

Beyth, M., 1972. The geology of central and western Tigre, Ethiopia. Unpublished Ph.D. dissertation, University of Bonn, Germany, 155 pp.

Boynton, W., 1984. Cosmochemistry of the rare earth elements: meteorite studies. In: Henderson, P. (Ed.), Rare Earth Element Geochemistry. Elsevier, Amsterdam, pp. 63-114.

Brand, U., Veizer, J., 1980. Chemical diagenesis of a multicomponent carbonate system: 1. Trace elements. J. Sediment. Petrol. 50, 1219-1236.

Brand, U., Veizer, J., 1981. Chemical diagenesis of a multicomponent carbonate system: 2. Stable isotopes. J. Sediment. Petrol. 51, 987-997.

Brasier, M., McCarron, G., Tucker, R., Leather, J., Shields, G., 2000. New U-Pb zircon dates for the Neoproterozoic Ghubrah glaciation and for the top of the Huqf Supergroup, Oman. Geology 28, 175-178.

Burns, S.J., Matter, A., 1993. Carbon isotopic record of the latest Proterozoic from Oman. Ecl. Geol. Helv. 86, 595-607.

Cocherie, A., Guerrot, C., Rossi, P.H., 1992. Single-zircon dating by stepwise $\mathrm{Pb}$ evaporation: comparison with other geochronological techniques applied to the Hercynian granites of Corsica, France. Chem. Geol. 101, 131-141.

Dalziel, I.W.D., 1997. Neoproterozoic-Paleozoic geography and tectonics: review, hypothesis, environmental speculation. Geol. Soc. Am. Bull. 109, 16-42.

Denison, R.E., Koepnick, R.B., Fletcher, A., Howell, M.W., Calloway, W.S., 1994. Criteria for the retention of original seawater ${ }^{87} \mathrm{Sr} /{ }^{86} \mathrm{Sr}$ in ancient shelf limestones. Chem. Geol. 112, 131-143.

Derry, L.A., Keto, L.S., Jacobsen, S.B., Knoll, A.H., Swett, K., 1989. $\mathrm{Sr}$ isotopic variations in upper Proterozoic carbonates from Svalbard and East Greenland. Geochim. Cosmochim. Acta 53, 2331-2339.

Derry, L.A., Kaufman, A.J., Jacobsen, S.B., 1992. Sedimentary cycling and environmental change in the later Proterozoic: evidence from stable and radiogenic isotopes. Geochim. Cosmochim. Acta 56, 1317-1329.
De Souza Filho, C.R., Drury, S.A., 1998. A Neoproterozoic supra-subduction terrane in northern Eritrea, NE Africa. J. Geol. Soc., London 155, 551-566.

Evans, D., 2000. Stratigraphic, geochronological, and paleomagnetic constraints upon the Neoproterozoic climatic paradox. Am. J. Sci. 300, 347-433.

Fairchild, I.J., Spiro, B., 1987. Petrological and isotopic implications of some contrasting late Precambrian carbonates, NE Spitsbergen. Sedimentology 34, 973-989.

Franzini, M., Leone, L., Saitta, M., 1972. Simple method to evaluate the matrix effect in X-ray fluorescence analysis. X-ray Spectrom. 1, 151-154.

Garland, C.R., 1972. The geological map of Adigrat area (1:250,000). Ministry of Mines, Addis Ababa.

Garland, C.R., 1980. Geology of the Adigrat area. Ministry of Mines Memoir, No. 1, Addis Ababa.

Hoffman, P.F., Schrag, D.P., 2002. The Snowball Earth hypothesis: testing the limits of global change. Terra Nova 14, 129-155.

Hoffman, P.F., Kaufman, A.J., Halverson, G.P., 1998a. Coming and goings of global glaciations on a Neoproterozoic tropical platform in Namibia. GSA Today 5, 1-9.

Hoffman, P.F., Kaufman, A.J., Halverson, G.P., Schrag, D.P., 1998b. A Neoproterozoic Snowball Earth. Science 281, 13421346.

Iyer, S.S., Babinski, M., Krouse, H.R., Chamele, F., 1995. Highly ${ }^{13} \mathrm{C}$-enriched carbonate and organic matter in the Neoproterozoic sediments of the Bambui Group, Brazil. In: Knoll, A.H., Walter, M. (Eds.), Neoproterozoic Stratigraphy and Earth History. Precambrian Res. 73, 271-282.

Jacobsen, S.B., Kaufman, A.J., 1999. The Sr, C and O isotopic evolution of Neoproterozoic seawater. Chem. Geol. 161, 37-57.

Jaeckel, P., Kröner, A., Kamo, S.L., Brandl, G., Wendt, J.I., 1997. Late archaean to early Proterozoic granitoid magmatism and high-grade metamorphism in the central Limpopo belt, South Africa. J. Geol. Soc., London 154, 25-44.

Kah, L., Sherman, A.G., Narbonne, G.M., Knoll, A.H., Kaufman, A.J., 1999. $\delta^{13} \mathrm{C}$ stratigraphy of the Bylot Supergroup, Baffin Island, Canada: extending the record of secular variations back into the Mesoproterozoic. Can. J. Earth Sci. 36, 313-332.

Karabinos, P., 1997. An evaluation of the single-grain zircon evaporation method in highly discordant samples. Geochim. Cosmochim. Acta 61, 2467-2474.

Kaufman, A.J., Knoll, A.H., 1995. Neoproterozoic variations in the C-isotopic composition of seawater: stratigraphic and biogeochemical implications. Precambrian Res. 73, 27-49.

Kaufman, A.J., Knoll, A.H., Butterfield, N.J., Hayes, J.M., 1990. The Neopreoterozoic carbon isotope record: its validity in chemostratigraphic correlation. Geol. Soc. Am. Abstr. Progr. $22,114$.

Kaufman, A.J., Hayes, J.M., Knoll, A.H., Germs, G.J.B., 1991. Isotopic compositions of carbonates and organic carbon from upper Proterozoic successions in Namibia: stratigraphic variation and the effects of diagenesis and metamorphism. Precambrian Res. 49, 301-327.

Kaufman, A.J., Jacobsen, S.B., Knoll, A.H., 1993. The Vendian record of $\mathrm{Sr}$ - and $\mathrm{C}$-isotopic variations in seawater: implications for tectonics and paleoclimate. Earth Planet. Sci. Lett. 120, 409-430. 
Kaufman, A.J., Knoll, A.H., Narbonne, G.M., 1997. Isotopes, ice ages and terminal Proterozoic earth history. Proc. Natl. Acad. Sci. U.S.A. 94, 6600-6605.

Kennedy, M.J., Runnegar, B., Brave, A.R., Hoffman, K.H., Arthur, M.A., 1998. Two or four Neoproterozoic glaciations? Geology 26, 1059-1063.

Knoll, A., 2000. Learning to tell Neoproterozoic time. Precambrian Res. 100, 3-20.

Knoll, A.H., Hayes, J.M., Kaufman, A.J., Swett, K., Lambert, I.B., 1986. Secular variation in carbon isotope ratios from upper Proterozoic successions of Svalbard and East Greenland. Nature 321, 832-838.

Kröner, A., 2001. The Mozambique belt of East Africa and Madagascar: significance of zircon and $\mathrm{Nd}$ model ages for Rodinia and Gondwana supercontinent formation and dispersal. S. Afr. J. Geol. 104, 151-166.

Kröner, A., Hegner, E., 1998. Geochemistry, single zircon ages and Sm-Nd systematics of granitoid rocks from the Góry Sowie (Owl) Mts., Polish West Sudetes: evidence for early Palaeozoic arc-related plutonism. J. Geol. Soc., London 155, 711-724.

Kröner, A., Byerly, G.R., Lowe, D.R., 1991. Chronology of early Archaean granite-greenstone evolution in the Barberton Mountain Land, South Africa, based on precise dating by single zircon evaporation. Earth Planet. Sci. Lett. 103, 41-54.

Kröner, A., Willner, A.P., Hegner, E., Nemchin, A., 2001. Single zircon ages, PT evolution and Nd isotopic systematics of high grade-grade gneisses in southern Malawi and their bearing on the extent of the Mozambique belt into southern Africa. Precambrian Res. 109, 257-291.

Kuznetsov, A.B., 1998. Evolution of $\mathrm{Sr}$ isotopic composition in late Riphean seawater: the Karatau Group carbonates, Southern Urals. Unpublished Ph.D. dissertation, St.-Petersburg. Int. Precambrian Geol. Geochronol, Russian Academy of Science, Russia (in Russian).

McCrea, J.M., 1959. On the isotope chemistry of carbonates and a paleotemperature scale. J. Chem. Phys. 18, 849-857.

Meert, J., 2003. A synopsis of events related to the assembly of eastern Gondwana. Tectonophysics 362, 1-40.

Melezhik, V.A., Gorokhov, I.M., Kuznetsov, A.B., Fallick, A.E., 2001. Chemostratigraphy for Neoproterozoic carbonates: implications for 'blind dating'. Terra Nova 13, 1-11.

Narbonne, G.M., Kaufman, A.J., Knoll, A.H., 1994. Integrated chemostratigraphy and biostratigraphy of the upper Windermere Supergroup (Neoproterozoic), Mackenzie Mountains, northwestern Canada. Geol. Soc. Am. Bull. 106, 12811291.
Patchett, J., Chase, C.G., 2002. Role of transform continental margins in major crustal growth episodes. Geology 30, 39-42.

Pearce, J.A., Harris, N.B.W., Tindle, A.G., 1984. Trace element discrimination diagrams for the tectonic interpretation of granitic rocks. J. Petrol. 25, 956-983.

Prave, A.R., 1999. Two diamictites, two cap carbonates, two $\delta^{13} \mathrm{C}$ excursions, two rifts: the Neoproterozoic Kingston Peak Formation, Death Valley, California. Geology 27, 339-342.

Russo, A., Fantozzi, P.L., Solomon, T., 1997. Geological map of Mekele outlier (western sheet, 1:100,000). Department of Earth Science, University of Sienna, Italy.

Stern, R.J., 1994. Neoproterozoic (900-550 Ma) arc assembly and continental collision in the East African Orogen. Annu. Rev. Earth Planet. Sci. 22, 319-351.

Stern, R.J., Abdelsalam, M.G., 1998. Formation of Juvenile Continental Crust in the Arabian-Nubian Shield: evidence from Granitic rocks of the Nakasib Suture, NE Sudan. Geologische Rundschau 87, 150-160.

Tadesse-Alemu, A., 1998. Geochemistry of Neoproterozoic granitoids from the Axum area, northern Ethiopia. J. Afr. Earth Sci. 27, 437-460.

Tadesse, T., Hoshino, M., Sawada, Y., 1999. Geochemistry of low-grade metavolcanic rocks from the Pan-African of the Axum area, northern Ethiopia. Precambrian Res. 99, 101-124.

Tadesse, T., Hoshino, M., Suzuki, K., Iisumi, S., 2000. Sm-Nd, $\mathrm{Rb}-\mathrm{Sr}$ and $\mathrm{Th}-\mathrm{U}-\mathrm{Pb}$ zircon ages of syn- and post-tectonic granitoids from the Axum area of northern Ethiopia. J. Afr. Earth Sci. 30, 313-327.

Teklay, M., 1997. Petrology, geochemistry and geochronology of Neoproterozoic magmatic arc rocks from Eritrea: implications for crustal evolution in the southern Nubian Shield, Eritrea Department of Mines, Memoir No. 1, 125 pp.

Tucker, M.E., 1985. Calcitized aragonitic ooids and cements from the late Precambrian Biri Formation of southern Norway. Sediment. Geol. 43, 67-84.

Veizer, J., Compston, W., Clauer, N., Schidlowski, M., 1983. ${ }^{87} \mathrm{Sr} /{ }^{86} \mathrm{Sr}$ in Late Proterozoic carbonates: evidence for a "mantle event" at $900 \mathrm{Ma}$ ago. Geochim. Cosmochim. Acta 47, 295-302.

Walter, M.R., Veevers, J.J., Calver, C.R., Hill, A.C., 2000. Dating the 840-544 Ma Neoproterozoic interval by isotopes of strontium, carbon, and sulfur in seawater and some interpretive models. Precambrian Res. 100, 371-433.

Whalen, J.B., Currie, K.L., Chappell, B.W., 1987. A-type granites geochemical characteristics, discrimination and petrogenesis. Contrib. Mineral. Petrol. 95, 407-419. 